\title{
Synthesis of Polymer-Based Magnetic Nanocomposite for Multi-Pollutants Removal from Water
}

\author{
Fatimah Mohammed Alzahrani ${ }^{1}$ (D), Norah Salem Alsaiari ${ }^{1, *}$, Khadijah Mohammedsaleh Katubi ${ }^{1, *}$ (D), \\ Abdelfattah Amari 2,3,*iD, Faouzi Ben Rebah 4,5,*iD and Mohamed A. Tahoon 4,6 D
}

1 Chemistry Department, College of Science, Princess Nourah bint Abdulrahman University, Riyadh 11671, Saudi Arabia; fmalzahrani@pnu.edu.sa

2 Department of Chemical Engineering, College of Engineering, King Khalid University, Abha 61411, Saudi Arabia

3 Research Laboratory, Department of Chemical Engineering, Energy and Environment, National School of Engineers, Gabes University, Gabes 6072, Tunisia

4 Department of Chemistry, College of Science, King Khalid University, Abha 61413, Saudi Arabia; tahooon_87@yahoo.com

5 Higher Institute of Biotechnology of Sfax (ISBS), Sfax University, Sfax 3000, Tunisia

6 Chemistry Department, Faculty of Science, Mansoura University, Mansoura 35516, Egypt

* Correspondence: nsalsaiari@pnu.edu.sa (N.S.A.); kmkatubi@pnu.edu.sa (K.M.K.); abdelfattah.amari@enig.rnu.tn (A.A.); benrebahf@yahoo.fr (F.B.R.)

Citation: Alzahrani, F.M.; Alsaiari, N.S.; Katubi, K.M.; Amari, A.; Ben Rebah, F.; Tahoon, M.A. Synthesis of Polymer-Based Magnetic Nanocomposite for Multi-Pollutants Removal from Water. Polymers 2021 13, 1742. https://doi.org/10.3390/ polym13111742

Academic Editor: Giulia Fredi

Received: 23 April 2021

Accepted: 25 May 2021

Published: 26 May 2021

Publisher's Note: MDPI stays neutral with regard to jurisdictional claims in published maps and institutional affiliations.

Copyright: (c) 2021 by the authors Licensee MDPI, Basel, Switzerland This article is an open access article distributed under the terms and conditions of the Creative Commons Attribution (CC BY) license (https:// creativecommons.org/licenses/by/ $4.0 /)$
Abstract: A magnetic polymer-based nanocomposite was fabricated by the modification of an $\mathrm{Fe}_{3} \mathrm{O}_{4} / \mathrm{SiO}_{2}$ magnetic composite with polypyrrole (PPy) via co-precipitation polymerization to form $\mathrm{PPy} / \mathrm{Fe}_{3} \mathrm{O}_{4} / \mathrm{SiO}_{2}$ for the removal of Congo red dye (CR) and hexavalent chromium $\mathrm{Cr}(\mathrm{VI})$ ions from water. The nanocomposite was characterized using various techniques including $\mathrm{X}$-ray diffraction (XRD), Fourier transform infrared spectroscopy (FTIR), scanning electron microscope (SEM), vibration sample magnetometer, and thermogravimetric analysis (TGA). The results confirm the successful fabrication of the nanocomposite in the size of nanometers. The effect of different conditions such as the contact time, adsorbent dosage, solution $\mathrm{pH}$, and initial concentration on the adsorption process was investigated. The adsorption isotherm suggested monolayer adsorption of both contaminants over the $\mathrm{PPy} / \mathrm{Fe}_{3} \mathrm{O}_{4} / \mathrm{SiO}_{2}$ nanocomposite following a Langmuir isotherm, with maximum adsorption of 361 and $298 \mathrm{mg}^{-1} \mathrm{~g}^{-1}$ for CR dye and $\mathrm{Cr}(\mathrm{VI})$, respectively. Furthermore, the effect of water type on the adsorption process was examined, indicating the applicability of the $\mathrm{PPy} / \mathrm{Fe}_{3} \mathrm{O}_{4} / \mathrm{SiO}_{2}$ nanocomposite for real sample treatment. Interestingly, the reusability of the nanocomposite for the removal of the studied contaminants was investigated with good results even after six successive cycles. All results make this nanocomposite a promising material for water treatment.

Keywords: polymers; magnetic nanomaterials; adsorption; Congo red removal; chromium removal

\section{Introduction}

Industrial wastewater treatment has become increasingly complex in recent decades as a result of the rapid industrialization and the presence of complex mixtures of toxic metal ions and organic dyes that harm human health and the environment [1-3]. The textile, paper, and plastic industries are the most common manufacturing purposes including dyes as important aromatic compounds [4]. In addition to their carcinogenic effects, contaminated drinking water with dyes causes various symptoms including severe headaches, skin irritation, and acute diarrhea [5]. Similarly, metal ions are not less dangerous than organic dyes due to their high toxicity when discharged in water supplies [6]. One of these toxic metals, hexavalent chromium $(\mathrm{Cr}(\mathrm{VI}))$, is classified as a very toxic and carcinogenic metal, causing nephritis, gastrointestinal ulceration, and cancer in the digestive tract [7]. The accepted concentrations of hexavalent chromium in drinking water and industrial 
wastewater are 5.0 and $200.0 \mu \mathrm{g} / \mathrm{L}$, respectively [8]. Therefore, the removal of such pollutants from water has become a challenge for environmental engineers. Several techniques have been applied for the removal of these harmful metallic ions and dyes from water and wastewater such as membrane filtration [9], photocatalytic reduction [10], biological treatment [11], precipitation [12], electrocoagulation [13], and adsorption [14,15].

The adsorption technique is considered as the most effective treatment method due to several reasons such as its high removal efficiency, economic viability, and simple processing, which make it a cost-effective method for pollutant removal from water [16-18]. Recently, nanomaterials with exceptional properties [19-22] have been found to be useful in different fields, especially water treatment. Magnetic nanoparticles as a class of nanomaterials have been widely used in different fields, due to their ease of separation using an external magnet, high specific surface area, and simple modification. Generally, these magnetic nanomaterials include elements with magnetic properties in their chemical structure such as iron, nickel, and cobalt. The exceptional properties of iron oxide $\left(\mathrm{Fe}_{3} \mathrm{O}_{4}\right)$ nanoparticles such as high adsorption, superparamagnetic behavior, good compatibility, low toxicity, high surface energy, and large surface area have attracted attention in recent years. Thus, these nanoparticles are appropriate for the elimination of targeted molecules. The toxicity and safety of using nanoparticles in water and food applications are important points. Interestingly, the non-toxicity of $\mathrm{Fe}_{3} \mathrm{O}_{4}$ allowed its wide applications in water and food fields among all other magnetic nanoparticles [23]. To increase the adsorption capacity and efficiency of $\mathrm{Fe}_{3} \mathrm{O}_{4}$ nanoparticles, they are usually modified by other organic or inorganic compounds to save the functional groups for capturing the target molecules. The surface of $\mathrm{Fe}_{3} \mathrm{O}_{4}$ magnetic nanoparticles can be easily modified using silica (silicon oxide) that has a high surface/volume ratio and, subsequently, can improve the adsorption capacity of $\mathrm{Fe}_{3} \mathrm{O}_{4}$ nanoparticles. Silica is widely used in different industries such as ceramics, ferrosilicon production, porcelain, and glassmaking, and as semiconductors in electronics [24]. This makes silica a promising material for different applications. The structural characteristics of silicon oxide allow carrying macromolecules such as proteins and polymers that associate the potential properties of polymers and the silica mechanical stability. This association of different properties is paving the way to numerous technological uses.

Among various polymers, polypyrrole (PPy) has received considerable interest due to its biocompatibility, low cost, excellent chemical stability, and conductivity. Moreover, PPy can be easily synthesized and used in different applications such as the nanomedicine sector, electrochemical sensors, and water treatment. In this context, the use of PPy to adsorb pollutants such as heavy metals has been reported [25-27]. Thus, PPy is an excellent choice for the modification of magnetic composites, especially the PPy polymer previously composited with magnetic nanoparticles for different applications such as lithium-ion batteries [28], due to its good compatibility with different nanoparticles.

Therefore, we can conclude that the use of composite materials for water treatment purposes can enhance the chelation and adsorption power of the materials toward targeted molecules. Herein, we synthesized an $\mathrm{Fe}_{3} \mathrm{O}_{4} / \mathrm{SiO}_{2} / \mathrm{PPy}$ magnetic nanocomposite for water treatment purposes. In the first part of the paper, we report the synthesis and characterization of the magnetic nanocomposite. In the second part of the paper, we report the application of the synthesized materials to the removal of $\mathrm{Cr}(\mathrm{VI})$ and Congo red dye with a discussion of the compositing process's role in the improvement of the material removal efficiency.

\section{Materials and Methods}

\subsection{Chemicals}

Congo red (97\%) and $\mathrm{K}_{2} \mathrm{Cr}_{2} \mathrm{O}_{7}(99.9 \%)$ were supplied by Sigma-Aldrich (Cairo, Egypt), while the monomer of pyrrole (98.0\%) was purchased from Merck Co. (Cairo, Egypt). Tetraethyl orthosilicate (TEOS, $98 \%$ ), aqueous ammonia (25\%), ammonium ferrous sulfate salts $(99 \%)$, and ferric chloride (98\%) were supplied by Sigma-Aldrich (Cairo, Egypt). 
Hydrochloric acid (35.0\%) and sodium hydroxide (97.0\%) for the $\mathrm{pH}$ adjustment were supplied by El Nasr Co. (Cairo, Egypt).

\subsection{Synthesis of $\mathrm{Fe}_{3} \mathrm{O}_{4} / \mathrm{SiO}_{2} / \mathrm{PPy}$ Magnetic Nanocomposite}

The synthesis of the $\mathrm{Fe}_{3} \mathrm{O}_{4} / \mathrm{SiO}_{2} / \mathrm{PPy}$ magnetic nanocomposite was achieved in three steps. The first step included the synthesis of $\mathrm{Fe}_{3} \mathrm{O}_{4}$ nanoparticles, which was followed by the second step consisting of the modification of $\mathrm{Fe}_{3} \mathrm{O}_{4}$ nanoparticles with $\mathrm{SiO}_{2}$. The third step included the formation of polypyrrole over the $\mathrm{Fe}_{3} \mathrm{O}_{4} / \mathrm{SiO}_{2}$ composite. For $\mathrm{Fe}_{3} \mathrm{O}_{4}$ nanoparticle synthesis, we followed the literature [29] in which hydrochloric acid $(\mathrm{HCl}$, $0.5 \mathrm{M}, 100 \mathrm{~mL})$ was used for dissolving ammonia iron sulfate $\left(\left(\mathrm{NH}_{4}\right)_{2} \mathrm{Fe}\left(\mathrm{SO}_{4}\right)_{2} \cdot 6 \mathrm{H}_{2} \mathrm{O}\right)$, $7.85 \mathrm{~g}$ ) and ferric chloride $\left(\mathrm{FeCl}_{3}, 10.82 \mathrm{~g}\right)$, followed by placing this mixture at $30^{\circ} \mathrm{C}$ in an ultrasound bath for half an hour. After that, the temperature of the mixture was adjusted at $80^{\circ} \mathrm{C}$, aqueous ammonia $(25 \%, 60 \mathrm{~mL})$ was added drop-wise, and the solution was stirred at $1500 \mathrm{rpm}$ to form the $\mathrm{Fe}_{3} \mathrm{O}_{4}$ nanoparticles as a black precipitate. The stirring process of the mixture was continued up to one hour followed by collecting the nanoparticles via an external magnet, and the collected $\mathrm{Fe}_{3} \mathrm{O}_{4}$ nanoparticles were washed several times with distilled water and dried for half a day at $70{ }^{\circ} \mathrm{C}$ in an oven. Finally, $\mathrm{Fe}_{3} \mathrm{O}_{4}$ nanoparticles were ready to be used. In the second step, $\mathrm{Fe}_{3} \mathrm{O}_{4}$ nanoparticles were modified with $\mathrm{SiO}_{2}$ by using tetraethyl orthosilicate (TEOS). This was achieved by using a mixture of distilled $\mathrm{H}_{2} \mathrm{O}(40 \mathrm{~mL})$ and ethyl alcohol $(99.9 \%, 170 \mathrm{~mL})$ to dissolve $2.0 \mathrm{~g}$ of synthesized $\mathrm{Fe}_{3} \mathrm{O}_{4}$ nanoparticles. Then, after adding $6 \mathrm{~mL}$ of aqueous ammonia, this mixture was placed for $15.0 \mathrm{~min}$ at $30{ }^{\circ} \mathrm{C}$ in an ultrasound bath. After the complete dispersion of $\mathrm{Fe}_{3} \mathrm{O}_{4}$ with vigorous stirring up to half a day under argon gas environment, $2 \mathrm{~mL}$ of TEOS was added to the solution. The synthesized $\mathrm{Fe}_{3} \mathrm{O}_{4} / \mathrm{SiO}_{2}$ was then collected by an external magnet, washed several times with absolute ethyl alcohol, and finally dried at $70{ }^{\circ} \mathrm{C}$ in an oven for four hours. The final step was the formation of PPy over the synthesized $\mathrm{Fe}_{3} \mathrm{O}_{4} / \mathrm{SiO}_{2}$ composite via the co-precipitation chemical method. In a glass beaker, $100 \mathrm{~mL}$ of distilled water was used to disperse $1.0 \mathrm{~g}$ of $\mathrm{Fe}_{3} \mathrm{O}_{4} / \mathrm{SiO}_{2}$ nanoparticles. For the complete dispersion of nanoparticles, the beaker was placed for $15.0 \mathrm{~min}$ at $30^{\circ} \mathrm{C}$ in an ultrasound bath. After that, the solution was stirred vigorously and during that, pyrrole $(0.1 \mathrm{M})$ was added and the stirring was continued up to two hours followed by the addition of ferric chloride $(0.1 \mathrm{M}$, $50.0 \mathrm{~mL}$ ); the reaction was continued for an additional three hours. Finally, the synthesized nanocomposite of $\mathrm{PPy} / \mathrm{Fe}_{3} \mathrm{O}_{4} / \mathrm{SiO}_{2}$ was collected by an external magnet, washed several times with absolute ethyl alcohol, and then dried in an oven at $60.0^{\circ} \mathrm{C}$ for $6.0 \mathrm{~h}$.

\subsection{Material Characterization}

The synthesized materials were characterized using various techniques including X-ray diffraction (XRD), magnetometer, Fourier transform infrared spectroscopy (FT-IR), scanning electron microscope (SEM), and thermogravimetric analysis (TGA) measurement. A GNR APD-2000 PRO (GNR, Cairo, Egypt) diffractometer was used to measure XRD using $\mathrm{Cu}$ Ka radiation $(\lambda=1.5406 \AA)$, operating at $45 \mathrm{kV}$. The diffraction intensities were recorded over $2 \theta$ ranging from $5^{\circ}$ to $60^{\circ}$ with a constant scanning rate of $1^{\circ} \mathrm{min}^{-1}$. A vibrating sample magnetometer (Lake Shore 7410, Lake Shore (Cryotronics Inc., Westerville, $\mathrm{OH}, \mathrm{USA}$ ) was used to measure the magnetization of the nanocomposite. A Bruker, Tensor 27 FT-IR (BRUKER, Karlsruhe, Germany) spectrophotometer was used to perform FTIR spectra in the range of $400-4000 \mathrm{~cm}^{-1}$ at room temperature and collected these at a resolution of $4 \mathrm{~cm}^{-1}$. An SEM Hitachi S4800 (Hitachi, Tokyo, Japan) was used to study the morphology of the synthesized material. A Perkin Elmer STA 6000 (PerkinElmer Inc., Shelton, USA) was used to measure the thermogravimetric analysis for the evaluation of thermal stability. 


\subsection{Adsorption Studies}

\subsubsection{The Effect of Contact Time}

The effect of the contact time on the removal of $\mathrm{Cr}(\mathrm{VI})$ and Congo red from water using the $\mathrm{PPy} / \mathrm{Fe}_{3} \mathrm{O}_{4} / \mathrm{SiO}_{2}$ nanocomposite was studied using a volume of $100 \mathrm{~mL}$ of contaminated water $\left(100 \mathrm{mg} . \mathrm{L}^{-1}\right)$ and adsorbent mass of $0.02 \mathrm{~g}$ at $\mathrm{pH}$ of 4.0. The solution shaking was conducted up to $24 \mathrm{~h}$ with sampling at various times to investigate the remaining contaminants using ICP and a UV-Vis spectrophotometer. The adsorbent was collected after each experiment using a magnet. All experiments were performed in triplicate.

\subsubsection{The Effect of Adsorbent Dosage}

Different masses of the adsorbent $\mathrm{PPy} / \mathrm{Fe}_{3} \mathrm{O}_{4} / \mathrm{SiO}_{2}$ nanocomposite were used to study the effect of adsorbent dosage on the removal of $\mathrm{Cr}(\mathrm{VI})$ and Congo red. The definite mass of adsorbent was mixed with $100.0 \mathrm{~mL}$ of polluted water with $\mathrm{pH}$ of $4.0 \mathrm{up}$ to $12 \mathrm{~h}$. When equilibrium was reached, the adsorbent was collected with a magnet, and the solution was examined for the presence of $\mathrm{Cr}(\mathrm{VI})$ and Congo red. Experiments were performed in triplicate.

\subsubsection{The Effect of Solution $\mathrm{pH}$}

A pH range of 3.0 to 7.0 was used to investigate the $\mathrm{pH}$ effect on the removal of $\mathrm{Cr}(\mathrm{VI})$ and Congo red using the $\mathrm{PPy} / \mathrm{Fe}_{3} \mathrm{O}_{4} / \mathrm{SiO}_{2}$ nanocomposite. The adsorbent mass used was $0.05 \mathrm{~g}$, the time was $12.0 \mathrm{~h}$, and the solution volume was $100.0 \mathrm{~mL}$. After each experiment, magnetic separation was used to collect the adsorbent, and the solution was examined for any residual pollutants using ICP and a UV-Vis spectrophotometer (Hach, CO, USA). Experiments were performed in triplicate.

\subsubsection{The Adsorption Isotherm}

To study the maximum adsorption capacity and the type of the adsorption process of $\mathrm{Cr}(\mathrm{VI})$ and Congo red over the synthesized $\mathrm{PPy} / \mathrm{Fe}_{3} \mathrm{O}_{4} / \mathrm{SiO}_{2}$ nanocomposite, the contaminated solution $(100.0 \mathrm{~mL})$ was mixed with $0.02 \mathrm{~g}$ of the composite for $24.0 \mathrm{~h}$ at $\mathrm{pH} 4.0$. The adsorption mechanism was represented by three isotherm models: Freundlich, Langmuir, and Temkin.

\subsubsection{The Regeneration Study}

To assess the commercial application of an adsorbent, it is necessary to determine the reusability of the material for the effective removal of contaminants several times. This was achieved by performing the adsorption experiment 6.0 successive times by mixing the contaminated water $\left(100 \mathrm{mg} . \mathrm{L}^{-1}, 100 \mathrm{~mL}, \mathrm{pH} 4.0\right)$ with adsorbent $(0.05 \mathrm{~g})$ for $12.0 \mathrm{~h}$. After each cycle, the adsorbent was collected with an external magnet, washed with distilled water extensively, and then dried at $50.0^{\circ} \mathrm{C}$ for $5.0 \mathrm{~h}$ to be used in the next cycle. Experiments were performed in triplicate.

\subsubsection{Water Type Effect}

Different types of water including wastewater, groundwater, tap water, and distilled water were used to determine the water type effect on the removal of $\mathrm{Cr}(\mathrm{VI})$ and Congo red using the synthesized $\mathrm{PPy} / \mathrm{Fe}_{3} \mathrm{O}_{4} / \mathrm{SiO}_{2}$ nanocomposite. Polluted solution prepared using target water with a concentration of $100.0 \mathrm{mg} . \mathrm{L}^{-1}$ and volume of $100.0 \mathrm{~mL}$ was mixed with $0.05 \mathrm{~g}$ of adsorbent for $12 \mathrm{~h}$. After each experiment, the solution was examined for the presence of contaminants.

\section{Results and Discussion}

\subsection{Nanocomposite Characterization}

The synthesized materials including $\mathrm{Fe}_{3} \mathrm{O}_{4}, \mathrm{Fe}_{3} \mathrm{O}_{4} / \mathrm{SiO}_{2}$, and $\mathrm{PPy} / \mathrm{Fe}_{3} \mathrm{O}_{4} / \mathrm{SiO}_{2}$ nanomaterials were investigated using different techniques such as X-ray diffraction (XRD), 
Fourier transform infrared spectroscopy (FT-IR), and scanning electron microscope (SEM). The XRD spectra of $\mathrm{Fe}_{3} \mathrm{O}_{4}$ nanoparticles, $\mathrm{Fe}_{3} \mathrm{O}_{4} / \mathrm{SiO}_{2}$, and $\mathrm{PPy} / \mathrm{Fe}_{3} \mathrm{O}_{4} / \mathrm{SiO}_{2}$ are shown in Figure 1a. The XRD of $\mathrm{Fe}_{3} \mathrm{O}_{4}$ nanoparticles alone indicated the cubic phase structure, and the peaks correspond to the (511), (422), (400), (311), and (220) crystalline planes [30]. The XRD of the $\mathrm{Fe}_{3} \mathrm{O}_{4} / \mathrm{SiO}_{2}$ composite showed the appearance of all $\mathrm{Fe}_{3} \mathrm{O}_{4}$ peaks with the reduction in the peak intensity and the disappearance of the peak at $2 \theta=20$ [31] indicating the crystallinity decrease in $\mathrm{Fe}_{3} \mathrm{O}_{4}$ by the combination with amorphous $\mathrm{SiO}_{2}$. The XRD of the PPy $/ \mathrm{Fe}_{3} \mathrm{O}_{4} / \mathrm{SiO}_{2}$ nanocomposite showed the appearance of all $\mathrm{Fe}_{3} \mathrm{O}_{4}$ peaks, and there was an overlap between the two peaks of $\mathrm{Fe}_{3} \mathrm{O}_{4}$ and PPy at $2 \theta=20$ that made this peak wider [32]. The diffraction intensity of this peak showed a clearly increase linked to the marked increase in the thickness of the polypyrrole shell, indicating the existence of amorphous polypyrrole in the sample. Additionally, the amorphous structure of $\mathrm{SiO}_{2}$ and PPy caused a reduction in the intensity of $\mathrm{Fe}_{3} \mathrm{O}_{4}$ peaks. This indicates the formation of the composite $\mathrm{PPy} / \mathrm{Fe}_{3} \mathrm{O}_{4} / \mathrm{SiO}_{2}$. The XRD results are in agreement with previous studies of $\mathrm{Fe}_{3} \mathrm{O}_{4}, \mathrm{Fe}_{3} \mathrm{O}_{4} / \mathrm{SiO}_{2}$, and PPy [31-33]. For the investigation of the functional groups present, the FT-IR spectra of $\mathrm{Fe}_{3} \mathrm{O}_{4}$ nanoparticles, $\mathrm{Fe}_{3} \mathrm{O}_{4} / \mathrm{SiO}_{2}$, and PPy $/ \mathrm{Fe}_{3} \mathrm{O}_{4} / \mathrm{SiO}_{2}$ are shown in Figure 1b. The FT-IR spectrum of $\mathrm{Fe}_{3} \mathrm{O}_{4}$ nanoparticles showed the appearance of an Fe-O band at $570 \mathrm{~cm}^{-1}$ with the appearance of a hydroxyl group band at $3418 \mathrm{~cm}^{-1}$, due to the existence of $\mathrm{H}_{2} \mathrm{O}$ in the nanoparticle structure [34]. In the spectra of $\mathrm{Fe}_{3} \mathrm{O}_{4} / \mathrm{SiO}_{2}$, the peaks appeared at $796 \mathrm{~cm}^{-1}$ and $1074 \mathrm{~cm}^{-1}$ and correspond to an Fe-O-Si bond and a Si-O bond, respectively. Additionally, the same peaks of $\mathrm{Fe}_{3} \mathrm{O}_{4}$ nanoparticles corresponding to hydroxyl group and $\mathrm{Fe}-\mathrm{O}$ are observed with a small shift due to the interaction between $\mathrm{Fe}_{3} \mathrm{O}_{4}$ and $\mathrm{SiO}_{2}$, while the FT-IR spectrum of the nanocomposite $\mathrm{PPy} / \mathrm{Fe}_{3} \mathrm{O}_{4} / \mathrm{SiO}_{2}$ showed the existence of all peaks corresponding to $\mathrm{Si}-\mathrm{O}-\mathrm{Fe}, \mathrm{Si}-\mathrm{O}$, and $\mathrm{Fe}-\mathrm{O}$ with a small shift due to the interaction between $\mathrm{Fe}_{3} \mathrm{O}_{4}$ and PPy [35]. Additionally, the $\mathrm{NOH}$ peak appeared at $934 \mathrm{~cm}^{-1}$ and the C-N peak appeared at $1192 \mathrm{~cm}^{-1}$. Additionally, the C-H vibrations were represented by the peaks at 1052,1300, and $1298 \mathrm{~cm}^{-1}$ [36]. The pyrrole ring vibrations were represented by the peaks at 1552 and $1547 \mathrm{~cm}^{-1}$. The wide peak observed at the range of 3500-3000 is characteristic of PPy composites, due to the N-H bonds' large number [28]. Furthermore, the $\mathrm{N}-\mathrm{H}$ and $\mathrm{O}-\mathrm{H}$ vibrations were represented by the peaks at 3447 and $3434 \mathrm{~cm}^{-1}[28,36]$. The results of FT-IR are in excellent agreement with previous studies of $\mathrm{Fe}_{3} \mathrm{O}_{4}, \mathrm{Fe}_{3} \mathrm{O}_{4} / \mathrm{SiO}_{2}$ [29], and PPy and its compounds [37].

An advantage of the present nanocomposite is its magnetic properties that allow its separation from the experimental media. Therefore, the magnetization curves of the synthesized materials $\mathrm{Fe}_{3} \mathrm{O}_{4}, \mathrm{Fe}_{3} \mathrm{O}_{4} / \mathrm{SiO}_{2}$, and $\mathrm{PPy} / \mathrm{Fe}_{3} \mathrm{O}_{4} / \mathrm{SiO}_{2}$ at room temperature are shown in Figure 1c. According to Figure 1c, the highest saturation magnetization was observed at 68 emu.g ${ }^{-1}$ for $\mathrm{Fe}_{3} \mathrm{O}_{4}$ nanoparticles. This value dropped to 35 emu.g ${ }^{-1}$ after the modification of $\mathrm{Fe}_{3} \mathrm{O}_{4}$ with silica, indicating the effective interaction between $\mathrm{Fe}_{3} \mathrm{O}_{4}$ and $\mathrm{SiO}_{2}$ [38]. Moreover, the successful modification of the composite $\mathrm{Fe}_{3} \mathrm{O}_{4} / \mathrm{SiO}_{2}$ with PPy was indicated by the dropped value of saturation magnetization to $8 \mathrm{emu} . \mathrm{g}^{-1}$, indicating that the $\mathrm{SiO}_{2}$ layer was thinner than the PPy layer [39]. It can be noticed that all synthesized materials have good magnetic properties, allowing magnetic separation using an external magnet, as shown in (Figure 1c, inset).

The thermal stability of the synthesized nanomaterials $\left(\mathrm{Fe}_{3} \mathrm{O}_{4}, \mathrm{Fe}_{3} \mathrm{O}_{4} / \mathrm{SiO}_{2}\right.$, and $\mathrm{PPy} / \mathrm{Fe}_{3} \mathrm{O}_{4} / \mathrm{SiO}_{2}$ ) was investigated using thermogravimetric analysis (TGA), as shown in Figure 1d. According to the TGA curve of $\mathrm{Fe}_{3} \mathrm{O}_{4}$, there is a minor weight loss (in the temperature range of room temperature to $10,000{ }^{\circ} \mathrm{C}$ ) equal to about $3.0 \%$ that is attributed to the evaporation of the chemical or physical attached water or hydroxyl groups on the surface of $\mathrm{Fe}_{3} \mathrm{O}_{4}$ nanoparticles. The TGA curve of $\mathrm{Fe}_{3} \mathrm{O}_{4} / \mathrm{SiO}_{2}$ indicated the successful deposition of thermally stable $\mathrm{SiO}_{2}$ on the $\mathrm{Fe}_{3} \mathrm{O}_{4}$ surface as there was only $3.5 \%$ weight loss in the temperature from room temperature to $161{ }^{\circ} \mathrm{C}$, which is attributed to the evaporation of adsorbed water. The TGA curve of the $\mathrm{PPy} / \mathrm{Fe}_{3} \mathrm{O}_{4} / \mathrm{SiO}_{2}$ nanocomposite showed $5.0 \%$ weight loss at the temperature range from room temperature to $300.0^{\circ} \mathrm{C}$, which is attributed to the removal of the PPy monomer and the evaporation of adsorbed water. Ppy chains 
have good thermal stability and can be destroyed at high temperatures only. This fact is indicated by the sharp peak at $640.0^{\circ} \mathrm{C}$ and weak peak at 400.0 to $500.0^{\circ} \mathrm{C}$. The low thermal stability of the PPy layer resulted in higher weight loss of $\mathrm{PPy} / \mathrm{Fe}_{3} \mathrm{O}_{4} / \mathrm{SiO}_{2}$ compared to $\mathrm{Fe}_{3} \mathrm{O}_{4} / \mathrm{SiO}_{2}$. The TGA results indicate the good incorporation of PPy and silica in the synthesized $\mathrm{PPy} / \mathrm{Fe}_{3} \mathrm{O}_{4} / \mathrm{SiO}_{2}$ nanocomposite.

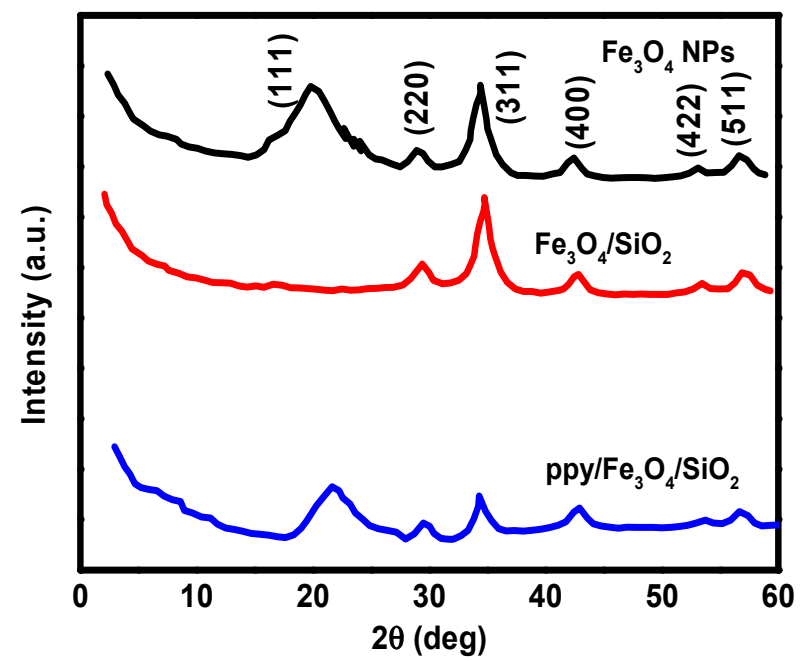

(a)

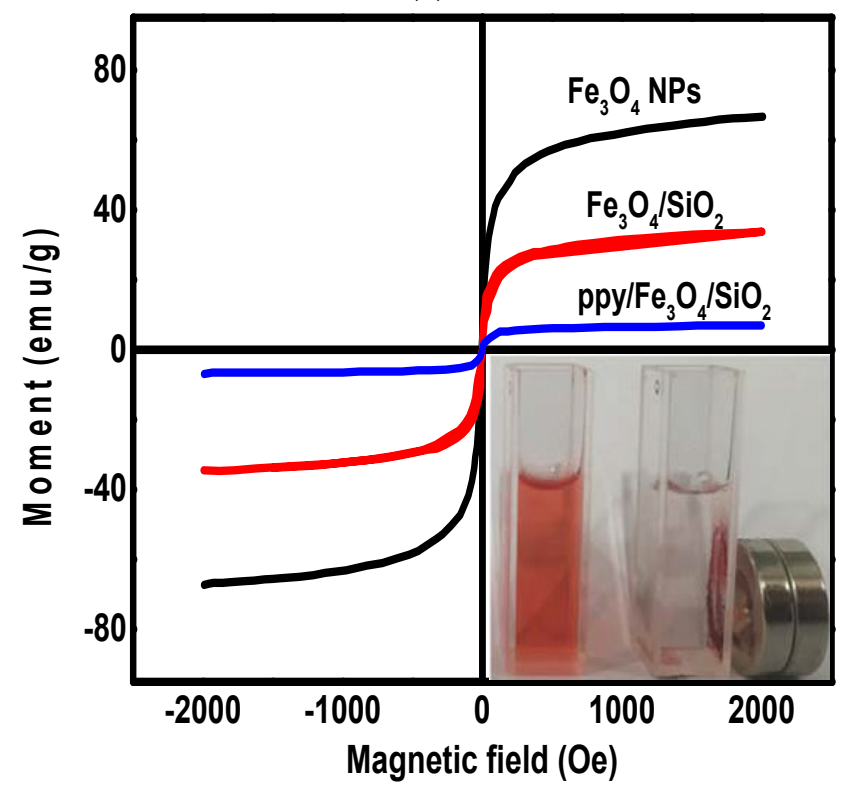

(c)

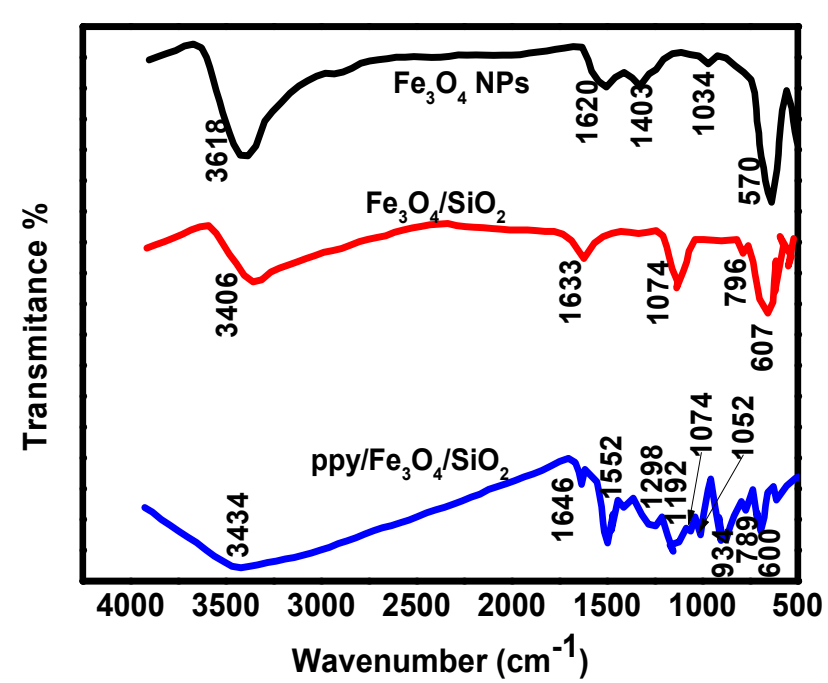

(b)

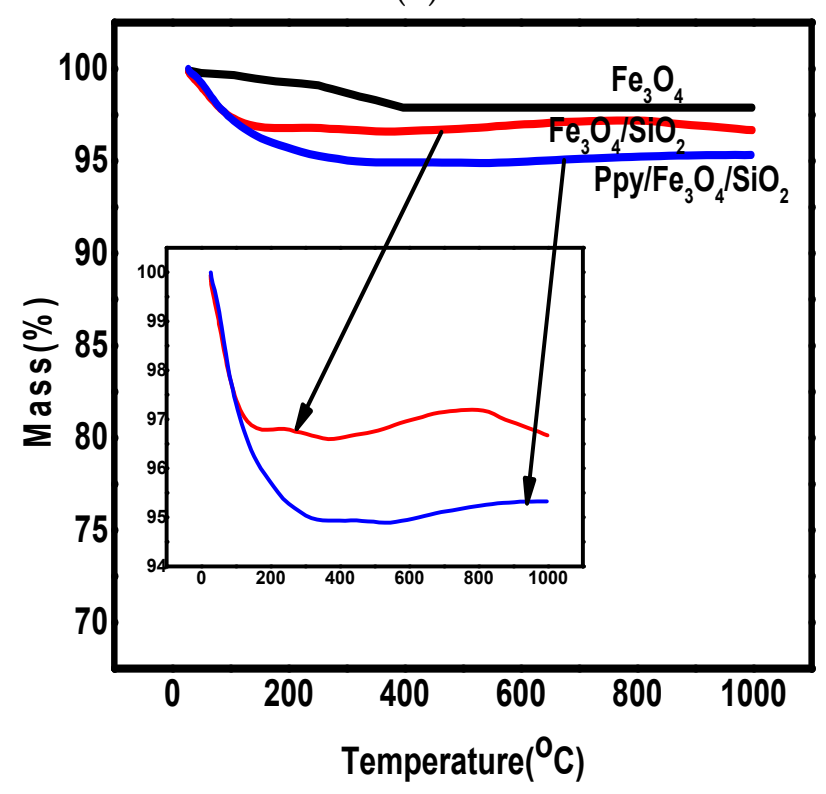

(d)

Figure 1. XRD (a), FT-IR (b), magnetization curves (c) (inset: separation of magnetic nanocomposite after adsorption with an external magnet), and thermogravimetric analysis (TGA) (d) of synthesized $\mathrm{Fe}_{3} \mathrm{O}_{4}$ nanoparticles, $\mathrm{Fe}_{3} \mathrm{O}_{4} / \mathrm{SiO}_{2}$ nanocomposite, and $\mathrm{PPy} / \mathrm{Fe}_{3} \mathrm{O}_{4} / \mathrm{SiO}_{2}$ nanocomposite.

For determining the surface structure and morphology of the synthesized materials, the SEM images were assessed (Figure 2).

The SEM image of $\mathrm{Fe}_{3} \mathrm{O}_{4}$ nanoparticles indicated their granular shape with a size range of 40.0 to $100.0 \mathrm{~nm}$ (in Figure 1a). Similar granular shapes with no big differences in porosity, morphology, and structure were observed between the $\mathrm{Fe}_{3} \mathrm{O}_{4} / \mathrm{SiO}_{2}$ composite (Figure 2b) and $\mathrm{Fe}_{3} \mathrm{O}_{4}$ nanoparticles. However, the morphology of the particles was changed by the addition of PPy, as shown in Figure 2c. The particles became cabbage in shape with an increase in their size as expected due to the deposition of pyrrole over $\mathrm{Fe}_{3} \mathrm{O}_{4}$ 
firstly, followed by the synthesis of PPy, causing the size increase. The present results are in agreement with the previous studies of $\mathrm{Fe}_{3} \mathrm{O}_{4}$ nanoparticles, $\mathrm{Fe}_{3} \mathrm{O}_{4} / \mathrm{SiO}_{2}$ composites [29], and PPy composites [40] from the view of particle shape, morphology, and porosity.

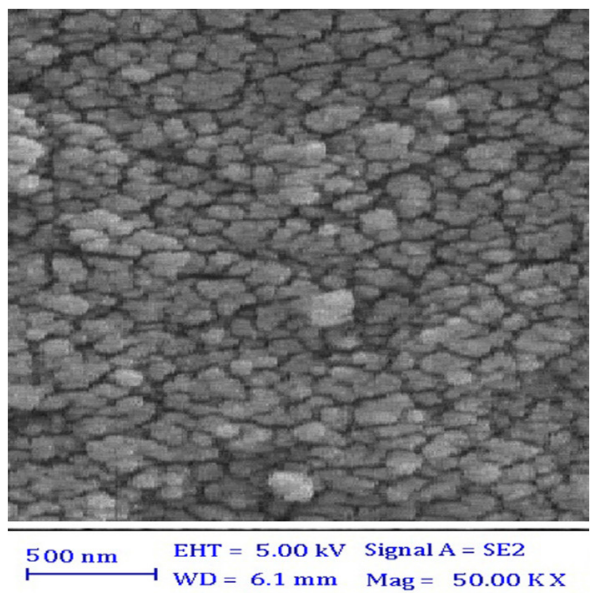

(a)

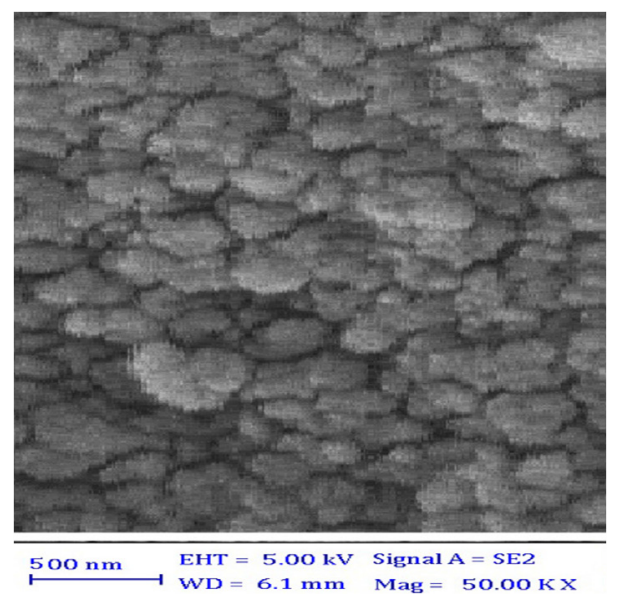

(b)

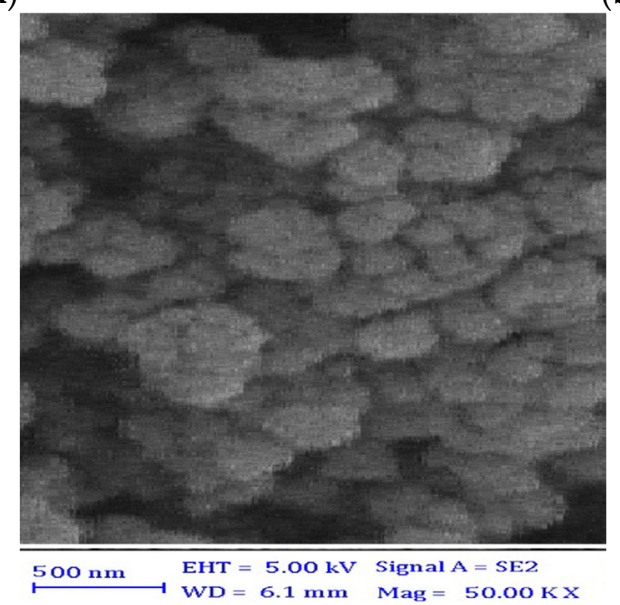

(c)

Figure 2. SEM images of $\mathrm{Fe}_{3} \mathrm{O}_{4}$ nanoparticles (a), $\mathrm{Fe}_{3} \mathrm{O}_{4} / \mathrm{SiO}_{2}$ nanocomposite (b), and $\mathrm{PPy} / \mathrm{Fe}_{3} \mathrm{O}_{4} / \mathrm{SiO}_{2}$ nanocomposite (c).

\subsection{Adsorption Studies}

\subsubsection{Effect of Contact Time}

The effect of the contact time on the removal of $\mathrm{Cr}(\mathrm{VI})$ and Congo red dye from water using the magnetic PPy $/ \mathrm{Fe}_{3} \mathrm{O}_{4} / \mathrm{SiO}_{2}$ nanocomposite was studied, as shown in Figure 3a. According to Figure $3 a$, there were two stages of removal of both pollutants. The first stage showed a rapid removal of $\mathrm{Cr}(\mathrm{VI})$ and Congo red dye that appeared in the plot as a linear curve. The second stage showed stable removal of $\mathrm{Cr}(\mathrm{VI})$ and Congo red dye, which appeared in the plot as a plateau curve, meaning that the adsorption process reached equilibrium.

This behavior can be explained in that the first stage occurred due to the existence of a large number of empty adsorption sites on the adsorbent surface, allowing the rapid capture of pollutants within a short period. After that, the adsorption sites became filled, and equilibrium was achieved [41,42]. According to Figure 3a, the $\mathrm{Cr}(\mathrm{VI})$ and Congo red dye removal by the magnetic $\mathrm{PPy} / \mathrm{Fe}_{3} \mathrm{O}_{4} / \mathrm{SiO}_{2}$ nanocomposite increased from 8.0 to $193.0 \mathrm{mg} . \mathrm{g}^{-1}$ and from 17.0 to $213.0 \mathrm{mg} . \mathrm{g}^{-1}$, respectively, when the contact time increased from 5.0 to $1440.0 \mathrm{~min}$. As clearly shown in the contact time plot, $480.0 \mathrm{~min}$ was the point at which equilibrium was reached for the removal of $\mathrm{Cr}(\mathrm{VI})$ and Congo red dye using the $\mathrm{PPy} / \mathrm{Fe}_{3} \mathrm{O}_{4} / \mathrm{SiO}_{2}$ nanocomposite. 


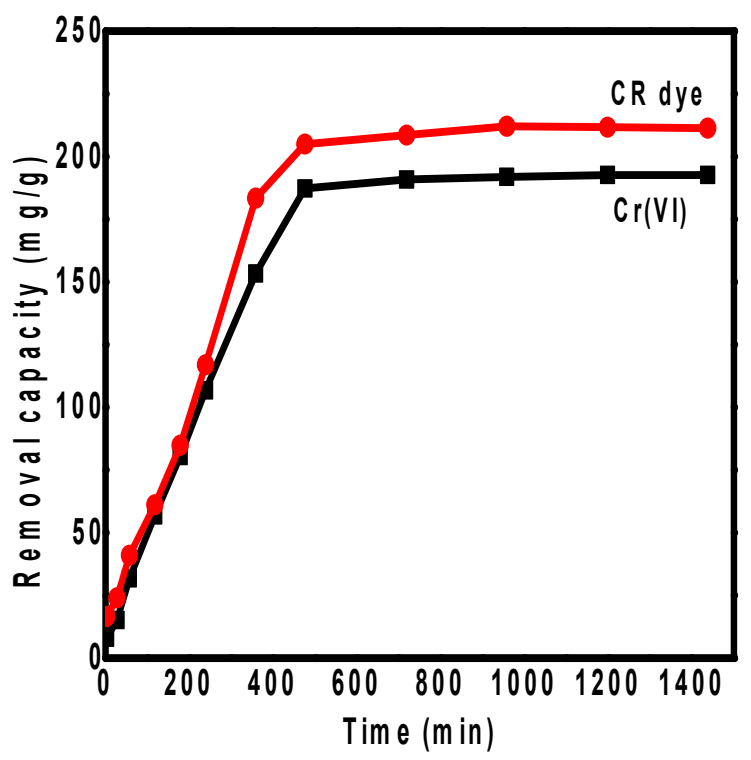

(a)

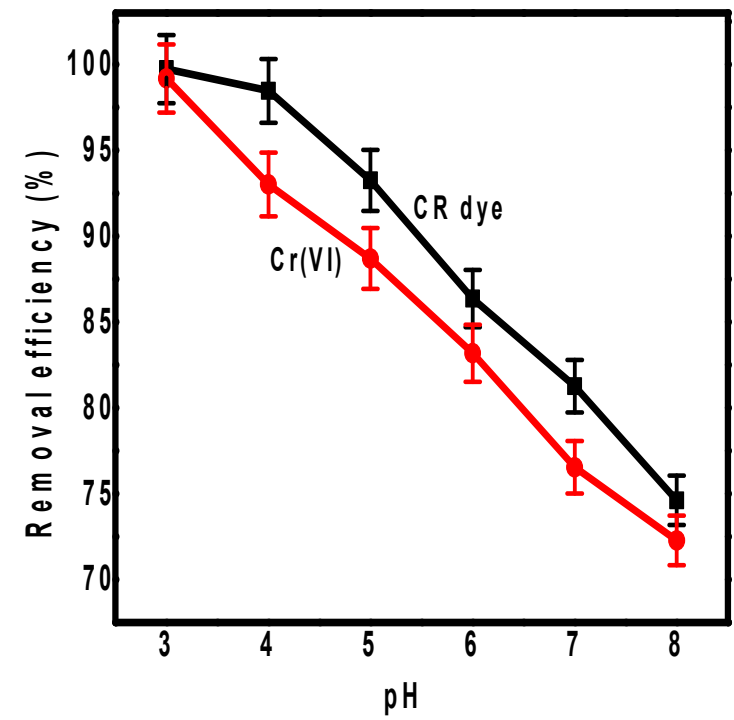

(c)

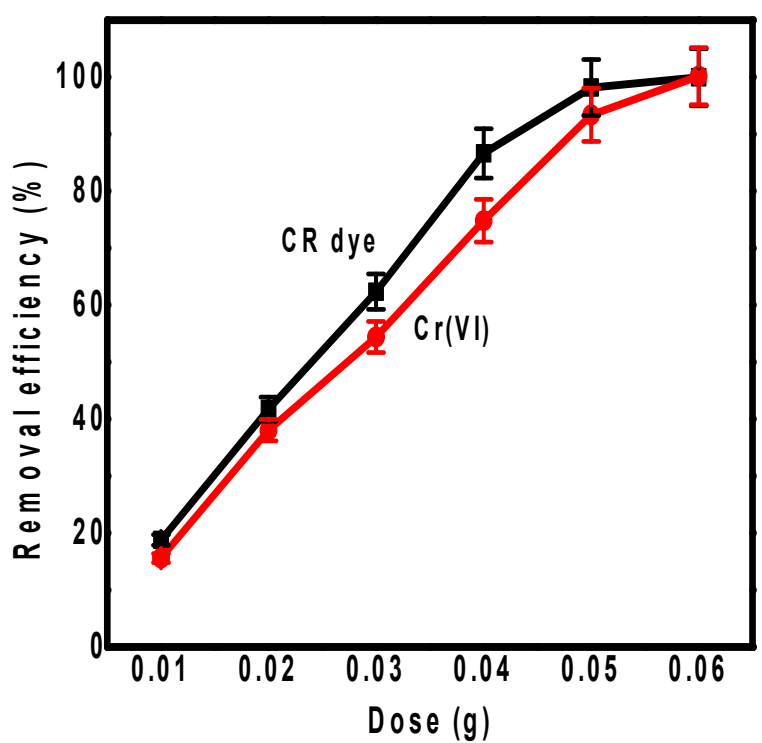

(b)

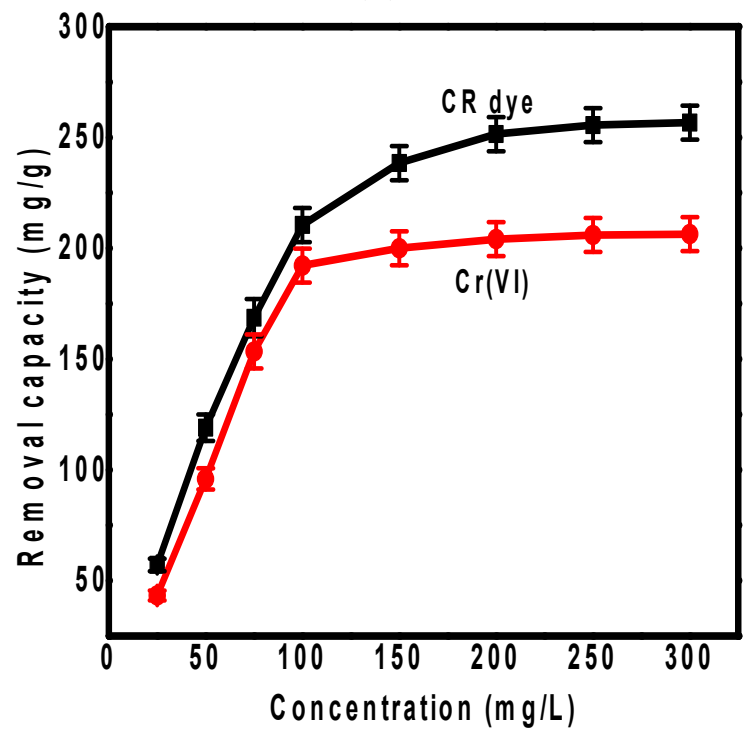

(d)

Figure 3. The contact time effect (a), adsorbent dosage effect (b), $\mathrm{pH}$ effect (c), and initial concentration effect (d) on the removal of Congo red dye and $\mathrm{Cr}(\mathrm{VI})$ from water using $\mathrm{PPy} / \mathrm{Fe}_{3} \mathrm{O}_{4} / \mathrm{SiO}_{2}$ nanocomposite.

\subsubsection{Effect of Adsorbent Dosage}

Figure $3 \mathrm{~b}$ shows the effect of adsorbent dosages on the removal of $\mathrm{Cr}(\mathrm{VI})$ and Congo red dye from water using the $\mathrm{PPy} / \mathrm{Fe}_{3} \mathrm{O}_{4} / \mathrm{SiO}_{2}$ nanocomposite. This was achieved using different masses of the nanocomposite as follows: $0.06,0.05,0.04,0.03,0.02$, and $0.01 \mathrm{~g}$. According to Figure $3 b$, the increased dose of the nanocomposite led to an increase in the removal percentage of both pollutants. This behavior is attributed to the existence of accessible and sufficient adsorption sites for the uptake of $\mathrm{Cr}(\mathrm{VI})$ and Congo red, which are increased by adding more quantities of the adsorbent, as reported in previous studies [43]. According to the Figure 3b, the removal efficiencies of $\mathrm{Cr}(\mathrm{VI})$ and Congo red were increased from $16.0 \%$ to $98.0 \%$ and from $19.0 \%$ to $99.5 \%$, respectively, when the mass of the $\mathrm{PPy} / \mathrm{Fe}_{3} \mathrm{O}_{4} / \mathrm{SiO}_{2}$ nanocomposite increased from 0.01 to $0.06 \mathrm{~g}$. When the adsorbent mass increased from 0.05 to $0.06 \mathrm{~g}$, there was no significant increase in the removal efficiencies. Therefore, $0.05 \mathrm{~g}$ was considered the optimum adsorbent dose for the removal of both contaminants using the $\mathrm{PPy} / \mathrm{Fe}_{3} \mathrm{O}_{4} / \mathrm{SiO}_{2}$ nanocomposite. This behavior may be attributed 
to the saturation of the adsorption sites or the agglomeration of adsorbent particles when their quantity increased, leading to the constant removal efficiency [44].

\subsubsection{Effect of Solution $\mathrm{pH}$}

The $\mathrm{pH}$ effect on the removal of $\mathrm{Cr}(\mathrm{VI})$ and Congo red using the $\mathrm{PPy} / \mathrm{Fe}_{3} \mathrm{O}_{4} / \mathrm{SiO}_{2}$ nanocomposite was investigated in the range of 3.0 to 8.0, as shown in Figure 3c. According to Figure $3 \mathrm{c}$, the highest removal efficiencies were achieved at the lowest $\mathrm{pH}$ (3.0 to 4.0) with removal values of $99.0 \%$ and $99.7 \%$ for $\mathrm{Cr}(\mathrm{VI})$ and Congo red, respectively. Moreover, the $\mathrm{pH}$ increase allowed a removal efficiency decrease for both $\mathrm{Cr}(\mathrm{VI})$ and Congo red. This behavior is attributed to many factors such as the charge in adsorbates and the adsorbent surface charge in the water environment. The increased removal efficiency at very low $\mathrm{pH}$ values is attributed to the high electrostatic attractions between the negatively charged adsorbates (acidic $\mathrm{CR}$ dye and $\mathrm{Cr}(\mathrm{VI})$ ) and the protonated adsorbent functional groups. The decreased removal efficiency at a higher $\mathrm{pH}$ value is attributed to the existence of negatively charged hydroxyl groups that compete with adsorbate molecules for adsorption active sites. Additionally, $\mathrm{Cr}_{2} \mathrm{O}_{7}{ }^{2-}$ and $\mathrm{HCrO}_{4}{ }^{-}$are the predominant ions of chromium in the $\mathrm{pH}$ range of (2.0 to 6.0), while this form changes by a pH increase to $\mathrm{HCrO}_{4}{ }^{2-}$. It is well known that the $\mathrm{HCrO}_{4}{ }^{-}$form of chromium ions has the lowest adsorption energy equal to ( 0.60 to $\left.2.50 \mathrm{kcal}^{\mathrm{mol}}{ }^{-1}\right)$ [45] that explains their high removal at a lower $\mathrm{pH}$. Moreover, at a low $\mathrm{pH}, \mathrm{H}^{+}$ions neutralize the negatively charged adsorbent surface, thereby reducing the barrier to diffusion of dichromate ions. However, the $\mathrm{pH}$ effect may be controlled by the development of an electric double layer over the adsorbent. With the increase in $\mathrm{pH}$, the concentration of $\mathrm{H}^{+}$ions changes from acidic to basic, and, consequently, the polarity of the double layer at the adsorbent surface may be changed from positive to negative. At a lower $\mathrm{pH}$, the system attained equilibrium faster and also the percentage of chromium adsorbed increased, as explained by Verma et al. [46]. Finally, we can conclude that the adsorption behavior at different $\mathrm{pH}$ values is dependent on the protonation or deprotonation of the adsorbent functional groups which detect the attraction or repulsion forces between these functional groups and metallic ions and dyes. Therefore, the adsorbent active binding sites and surface chemistry of the material are clearly influenced by the $\mathrm{pH}$, which affects the efficiency of the adsorption.

\subsubsection{Initial Concentration Effect}

Figure $3 \mathrm{~d}$ shows the effect of using different Congo red dye and $\mathrm{Cr}(\mathrm{VI})$ initial concentrations on their adsorption over the PPy $/ \mathrm{Fe}_{3} \mathrm{O}_{4} / \mathrm{SiO}_{2}$ nanocomposite. This was achieved by using a concentration range of 25.0-300.0 mg. $\mathrm{L}^{-1}$ for both Congo red dye and $\mathrm{Cr}(\mathrm{VI})$. According to Figure $3 \mathrm{~d}$, the adsorption capacity increased by increasing the initial concentration of Congo red dye and $\mathrm{Cr}(\mathrm{VI})$, and at a certain point, equilibrium was reached (the adsorption increase became slower). Equilibrium was reached at $100.0 \mathrm{mg} . \mathrm{L}^{-1}$ for both Congo red dye and $\mathrm{Cr}(\mathrm{VI})$, which is considered the optimum initial concentration. The maximum adsorption capacities reached $207.0 \mathrm{mg} . \mathrm{L}^{-1}$ and $257.0 \mathrm{mg} . \mathrm{L}^{-1}$ for $\mathrm{Cr}(\mathrm{VI})$ and Congo red dye, respectively. These highest values of pollutant removal at higher concentrations could be explained on the basis of the high attraction forces between pollutants and the adsorbent surface at high concentrations.

\subsubsection{Adsorption Isotherm}

Freundlich, Langmuir, and Temkin adsorption isotherms were used to investigate the adsorption isotherm of Congo red dye and $\mathrm{Cr}(\mathrm{VI})$ ions over the surface of the $\mathrm{PPy} / \mathrm{Fe}_{3} \mathrm{O}_{4} / \mathrm{SiO}_{2}$ nanocomposite. The main purpose of studying the adsorption isotherm is to understand the adsorption mechanism over the studied adsorbent (i.e., assess the adsorption limit and the distribution of the pollutants on the adsorbent sites). The fitting of isotherms is presented in Figure 4. 


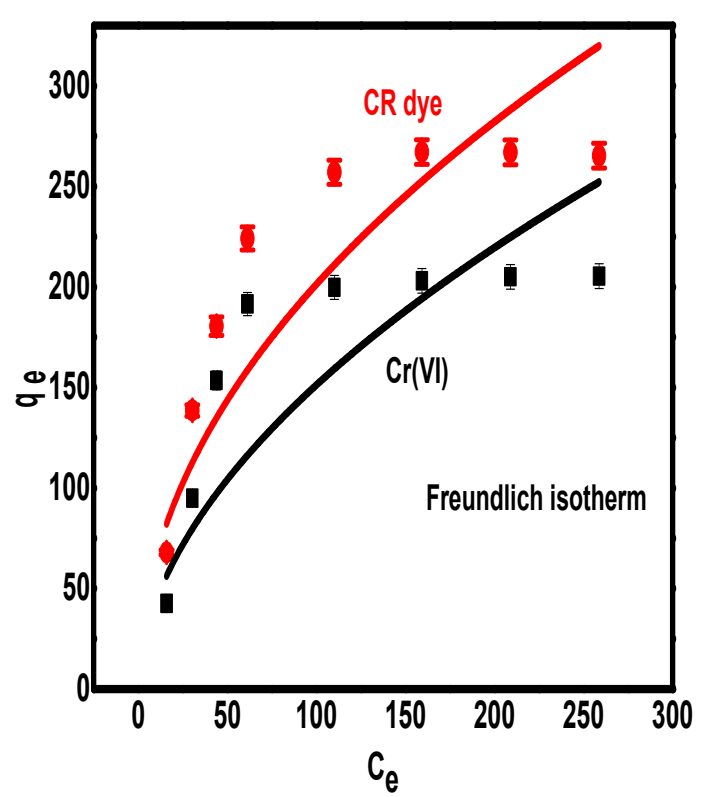

(a)

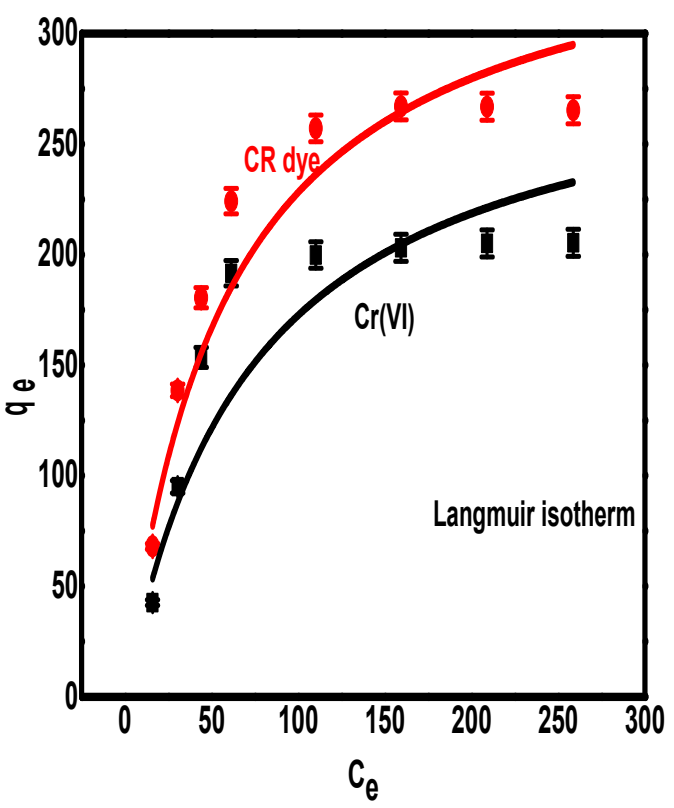

(b)

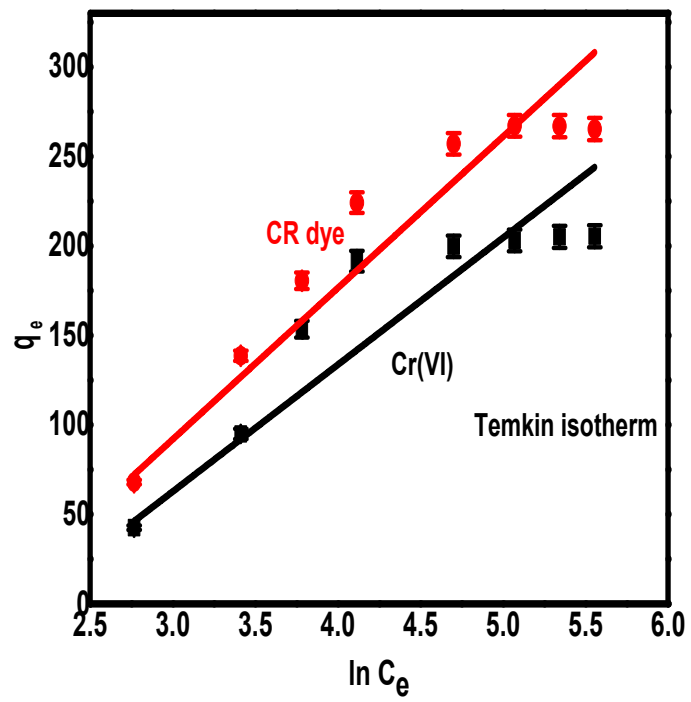

(c)

Figure 4. Plotting of Freundlich isotherm (a), Langmuir isotherm (b), and Temkin isotherm (c) for the removal of Congo red dye and $\mathrm{Cr}(\mathrm{VI})$ metal ions over the $\mathrm{PPy} / \mathrm{Fe}_{3} \mathrm{O}_{4} / \mathrm{SiO}_{2}$ nanocomposite.

The first studied isotherm was the Freundlich model that suggested heterogeneous adsorption of contaminants over the surface of the adsorbent, and the adsorption was achieved via the construction of multilayers from the pollutant ions [47]. The Freundlich model can be represented by the equation

$$
\mathrm{q}_{\mathrm{e}}=\mathrm{K}_{\mathrm{F}}+\mathrm{C}_{\mathrm{e}}{ }^{\mathrm{N}}
$$

where $\mathrm{q}_{\mathrm{e}}$ denotes the amount of uptake pollutants after equilibration $\left(\mathrm{mg} \cdot \mathrm{g}^{-1}\right), \mathrm{C}_{\mathrm{e}}$ denotes the rest concentrations (mg. $\mathrm{L}^{-1}$ ), and $\mathrm{N}$ and $\mathrm{K}_{\mathrm{F}}$ are the normal constants of the Freundlich model and related to the adsorption intensities and capacities, respectively.

The second studied isotherm was the Langmuir model that suggested homogenous adsorption of contaminants over the surface of the adsorbent, and the adsorption was 
achieved via the construction of a monolayer from the pollutant ions [48]. The Langmuir model can be represented by the equation

$$
\mathrm{q}_{\mathrm{e}}=\mathrm{K}_{\mathrm{L}} \mathrm{q}_{\mathrm{m}} /\left(1+\mathrm{K}_{\mathrm{L}} \mathrm{C}_{\mathrm{e}}\right),
$$

where $\mathrm{K}_{\mathrm{L}}$ denotes the Langmuir constant and $\mathrm{q}_{\mathrm{m}}$ denotes maximum adsorption after reaching saturation.

The last model is the Temkin isotherm that indicates the effect of sorbate ions on each other during the adsorption process. The Temkin model can be represented by the equation

$$
\mathrm{q}_{\mathrm{e}}=\mathrm{B} \ln \mathrm{A}+\mathrm{B} \ln \mathrm{C}_{\mathrm{e}},
$$

where B and A denote Temkin model constants. Table 1 summarizes the Freundlich and Langmuir parameters for the removal of Congo red dye and $\mathrm{Cr}(\mathrm{VI})$ ions over the $\mathrm{PPy} / \mathrm{Fe}_{3} \mathrm{O}_{4} / \mathrm{SiO}_{2}$ nanocomposite.

Table 1. The calculated Langmuir and Freundlich isotherm parameters for the removal of $\mathrm{Cr}(\mathrm{VI})$ and

\begin{tabular}{|c|c|c|c|c|c|c|c|c|c|}
\hline \multirow{2}{*}{ Pollutant } & \multicolumn{4}{|c|}{ Langmuir } & \multicolumn{2}{|c|}{ Freundlich } & \multicolumn{3}{|c|}{ Temkin } \\
\hline & $\begin{array}{c}\mathrm{q}_{\max } \\
\left(\mathrm{mg} \cdot \mathrm{g}^{-1}\right)\end{array}$ & $\begin{array}{c}\mathrm{K}_{\mathrm{L}} \\
\text { (L.mg. }\end{array}$ & $\mathrm{R}^{2}$ & $\mathrm{~N}$ & $\begin{array}{c}\mathrm{K}_{\mathrm{F}} \\
\text { (L.mg.g }\end{array}$ & $\mathrm{R}^{2}$ & $\begin{array}{c}\mathrm{B} \\
\text { (J.mol }\end{array}$ & $\begin{array}{c}\mathrm{A} \\
\left(\mathrm{L} \cdot \mathrm{g}^{-1}\right)\end{array}$ & $\mathrm{R}^{2}$ \\
\hline $\begin{array}{l}\text { CR } \\
\text { dye }\end{array}$ & 361.43 & 0.017 & 0.946 & 0.487 & 2.1360 & 0.842 & 69.44 & 4.33 & 0.931 \\
\hline $\mathrm{Cr}(\mathrm{VI})$ & 298.22 & 0.013 & 0.892 & 0.537 & 1.2720 & 0.785 & 57.12 & 4.52 & 0.835 \\
\hline
\end{tabular}
$\mathrm{CR}$ dye over $\mathrm{PPy} / \mathrm{Fe}_{3} \mathrm{O}_{4} / \mathrm{SiO}_{2}$ nanocomposite.

According to the data in Table 1, there was a lower fit of the Freundlich and Temkin isotherms than the Langmuir isotherm for the adsorption of Congo red dye and $\mathrm{Cr}(\mathrm{VI})$ metal on the surface of the $\mathrm{PPy} / \mathrm{Fe}_{3} \mathrm{O}_{4} / \mathrm{SiO}_{2}$ nanocomposite, as indicated from the values of $\mathrm{R}^{2}$. The maximum adsorption capacities of the $\mathrm{PPy} / \mathrm{Fe}_{3} \mathrm{O}_{4} / \mathrm{SiO}_{2}$ nanocomposite calculated using the Langmuir model were found to be $298.22 \mathrm{mg} \cdot \mathrm{g}^{-1}$ and $361.43 \mathrm{mg} \cdot \mathrm{g}^{-1}$ for $\mathrm{Cr}(\mathrm{VI})$ and Congo red dye, respectively. Subsequently, the adsorption of $\mathrm{Cr}(\mathrm{VI})$ and Congo red dye on the surface of the $\mathrm{PPy} / \mathrm{Fe}_{3} \mathrm{O}_{4} / \mathrm{SiO}_{2}$ nanocomposite was achieved in the form of monolayer uptake on the energetically symmetrical (homogeneous) adsorption sites. Additionally, the values of $\mathrm{N}$ obtained from fitting of the experimental data with the Freundlich isotherm were higher than zero, indicating the favorable adsorption of both pollutants. Additionally, the experimental data also fitted the Temkin model, indicating that the adsorption process was possibly affected by pollutant ion interactions.

\subsubsection{The Regeneration Study}

The application of any studied adsorbent at a large scale for wastewater treatment essentially requires an investigation of its regeneration $[49,50]$. Concerning this, the reusability of the $\mathrm{PPy} / \mathrm{Fe}_{3} \mathrm{O}_{4} / \mathrm{SiO}_{2}$ nanocomposite for the removal of $\mathrm{Cr}(\mathrm{VI})$ ions and Congo red dye was studied for up to six successive cycles, as shown in Figure 5a.

After each cycle, the adsorbent was separated using an external magnet, washed several times extensively with distilled water to remove any adhered pollutants, and then dried in an oven to be used in the next adsorption-desorption cycle. The studied $\mathrm{PPy} / \mathrm{Fe}_{3} \mathrm{O}_{4} / \mathrm{SiO}_{2}$ nanocomposite showed good reusability for the removal of $\mathrm{Cr}(\mathrm{VI})$ and Congo red dye during the studied cycles, with a decrease in the efficiencies by increasing the cycles. The composite's efficiency to remove Congo red dropped from $98.0 \%$ to $74.0 \%$, while for $\mathrm{Cr}(\mathrm{VI})$ removal, it dropped from $93.0 \%$ to $72.0 \%$ after six reuse cycles. This behavior is attributed to the destroyed adsorption sites over the nanocomposite surface after each cycle, causing the decrease in the material efficiency to capture the pollutants. 


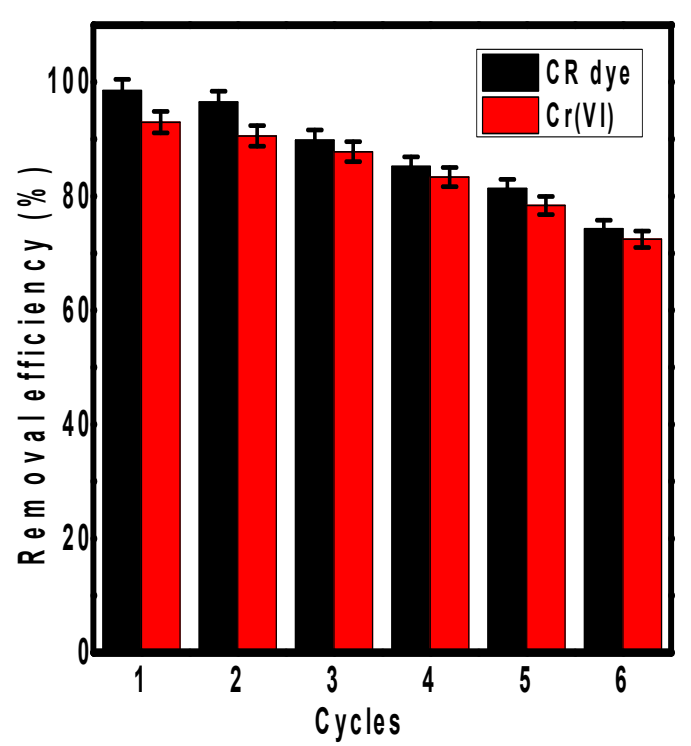

(a)

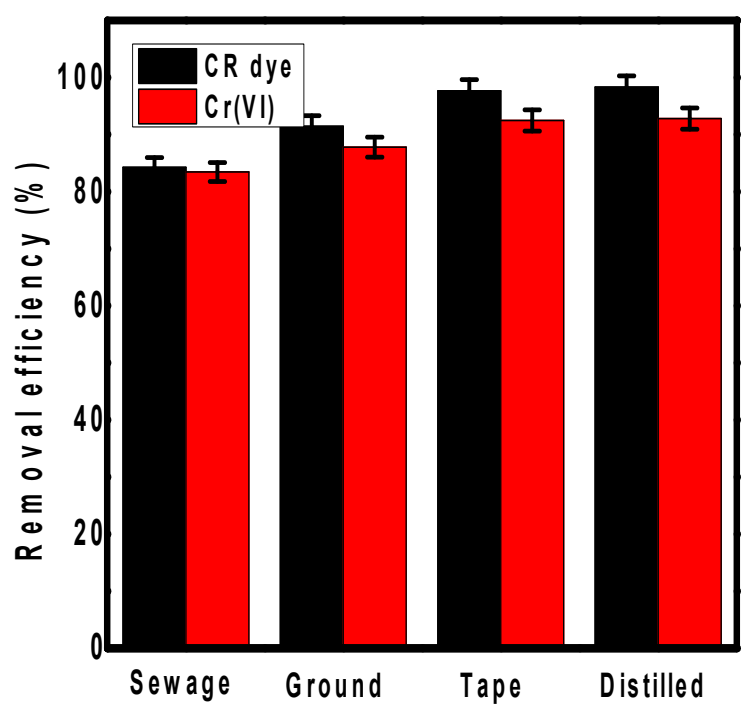

(b)

Figure 5. The regeneration study of $\mathrm{PPy} / \mathrm{Fe}_{3} \mathrm{O}_{4} / \mathrm{SiO}_{2}$ nanocomposite for the removal of Congo red dye and $\mathrm{Cr}(\mathrm{VI})$ up to six successive cycles (a) and the effect of water type (b).

\subsubsection{The Water Type Effect}

The removal efficiency of $\mathrm{Cr}(\mathrm{VI})$ ions and Congo red dye on the surface of the $\mathrm{PPy} / \mathrm{Fe}_{3} \mathrm{O}_{4} / \mathrm{SiO}_{2}$ nanocomposite using different types of water including sewage water, groundwater, tap water, and distilled water was investigated to determine the applicability of the synthesized nanocomposite for an effective real water treatment (Figure $5 b$ ). The order of the removal efficiency for both pollutants $(\mathrm{Cr}(\mathrm{VI})$ and Congo red dye) was distilled water $>$ tap water $>$ groundwater $>$ sewage water. This resulting behavior is attributed to the existence of other contaminants in each water type that compete with the studied pollutants for the adsorption active sites over the nanocomposite surface. Furthermore, the selectivity of any innovative adsorbent should be studied toward different competing co-ions including bicarbonate, sulfate, and chloride ions that may be present in water. For example, it was reported that sulphate and chloride negatively affect the adsorption of $\mathrm{Cr}(\mathrm{VI})$ on polypyrrole@magnetic chitosan nanocomposites [51]. Additionally, the similarity of the ionic charge between $\mathrm{Cr}(\mathrm{VI})$ and bicarbonate ions showed a competitive effect on the adsorption of $\mathrm{Cr}(\mathrm{VI})[51,52]$. Therefore, it is very important to determine the chemical composition of the water before starting the adsorption experiments. Matched to the reported concentrations in nature, these removal efficiencies were achieved for a pollutant concentration of $100.0 \mathrm{mg} . \mathrm{L}^{-1}$, which is considered high. This fact approves the applicability of the $\mathrm{PPy} / \mathrm{Fe}_{3} \mathrm{O}_{4} / \mathrm{SiO}_{2}$ nanocomposite for real water treatment.

\subsubsection{Comparative Study}

The assessment of the synthesized nanocomposite for the removal of Congo red dye and $\mathrm{Cr}(\mathrm{VI})$ ions required its comparison with previously reported adsorbents. In this regard, we summarized the previously studied adsorbents for the removal of Congo red dye and $\mathrm{Cr}(\mathrm{VI})$ ions in Table 2. According to Table 2 [53-68], it is noticeable that the present synthesized $\mathrm{PPy} / \mathrm{Fe}_{3} \mathrm{O}_{4} / \mathrm{SiO}_{2}$ nanocomposite showed a good removal capacity for the removal of $\mathrm{Cr}(\mathrm{VI})$ ions and Congo red dye when compared to previously reported materials. However, the difference in the adsorbent efficiency between materials may be controlled by the variability of the interactions between pollutants and the material functional groups. Strong interactions with specific functional groups present on the adsorbent surface allow a high adsorption capacity [67]. Furthermore, the competitive potential application of these innovative adsorbents should be evaluated taking into consideration different parameters associated with the material characteristics (regeneration, degradation, life cycle, etc.) and 
with the wastes resulting from the process (loaded pollutant disposal, chemicals used for the adsorption-desorption, etc.). Moreover, a cost comparison between these materials should be conducted.

Table 2. Comparative assessment of $\mathrm{CR}$ dye and $\mathrm{Cr}(\mathrm{VI})$ ions adsorption capacity of $\mathrm{PPy} / \mathrm{Fe}_{3} \mathrm{O}_{4} / \mathrm{SiO}_{2}$ nanocomposite with previously reported adsorbents.

\begin{tabular}{|c|c|c|c|}
\hline Adsorbent & Pollutant & $\mathrm{q}_{\mathrm{m}}\left(\mathrm{mg} \cdot \mathrm{g}^{-1}\right)$ & Ref. \\
\hline $\mathrm{PPy} / \mathrm{Fe}_{3} \mathrm{O}_{4} / \mathrm{SiO}_{2}$ & CR dye and $\mathrm{Cr}(\mathrm{VI})$ & 361.43 and 298.22 & This study \\
\hline $\mathrm{PPy} / \mathrm{Fe}_{3} \mathrm{O}_{4} / \mathrm{AgCl}$ & $\mathrm{Cr}(\mathrm{VI})$ & 111 & [52] \\
\hline PPy-rGO/ $\mathrm{Fe}_{3} \mathrm{O}_{4}$ & $\mathrm{Cr}(\mathrm{VI})$ & 227 & [53] \\
\hline PPy-coated halloysite nanotubes & $\mathrm{Cr}(\mathrm{VI})$ & 149 & {$[54]$} \\
\hline PPy-PANI fibers & $\mathrm{Cr}(\mathrm{VI})$ & 227 & [55] \\
\hline Glycine-doped PPy & $\mathrm{Cr}(\mathrm{VI})$ & 217 & {$[56]$} \\
\hline $\mathrm{PPy} / \mathrm{Fe}_{3} \mathrm{O}_{4}$ & $\mathrm{Cr}(\mathrm{VI})$ & 169 & [57] \\
\hline $\mathrm{Fe}_{3} \mathrm{O}_{4}$ glycine-doped PPy & $\mathrm{Cr}(\mathrm{VI})$ & 238 & [58] \\
\hline Aspartic acid-doped PPy & $\mathrm{Cr}(\mathrm{VI})$ & 177 & [59] \\
\hline Hierarchical porous $\mathrm{MgBO}_{2}(\mathrm{OH})$ microspheres & CR dye & 228 & {$[60]$} \\
\hline Mesoporous activated carbon & CR dye & 189 & [61] \\
\hline $\mathrm{NiO}$ nanosheets & CR dye & 168 & {$[62]$} \\
\hline $\mathrm{MgO}$ powders & CR dye & 105 & [63] \\
\hline Neem leaf powder2 & CR dye & 41 & [64] \\
\hline Magnetic core-manganese oxide shell & CR dye & 42 & {$[65]$} \\
\hline Chitosan/montmorillonite nanocomposite & CR dye & 55 & {$[66]$} \\
\hline Ashitaba waste-based activated carbons & CR dye & $289-381$ & [67] \\
\hline Walnut shell-based activated carbons & CR dye & $314-400$ & [68] \\
\hline Nanofibrous membranes from ion polymers & CR dye & 70.8 & [69] \\
\hline
\end{tabular}

\section{Conclusions}

In this study, a promising polymer-based nanocomposite, $\mathrm{PPy} / \mathrm{Fe}_{3} \mathrm{O}_{4} / \mathrm{SiO}_{2}$, was synthesized for the elimination of Congo red dye and $\mathrm{Cr}(\mathrm{VI})$ from water. The synthesized nanocomposite was characterized using different techniques (XRD, FT-IR, SEM, etc.). XRD results confirmed the crystalline structure of $\mathrm{Fe}_{3} \mathrm{O}_{4}$ nanoparticles that decreased by the addition of PPy and silica. Additionally, SEM images confirmed the size of the synthesized materials. FT-IR bands approved the successful combination between three components of the hybrid $\mathrm{Fe}_{3} \mathrm{O}_{4}, \mathrm{SiO}_{2}$, and PPy. The synthesized nanocomposite was examined for the removal of $\mathrm{Cr}(\mathrm{VI})$ and Congo red dye from water. The effects of different factors including the contact time, adsorbent dosage, solution $\mathrm{pH}$, and initial concentration on the adsorption process were studied to detect the optimum conditions. The adsorption data were found to be more fitting to the Langmuir model with maximum adsorption of $298.22 \mathrm{mg} . \mathrm{g}^{-1}$ and $361.43 \mathrm{mg} \cdot \mathrm{g}^{-1}$ for the removal of $\mathrm{Cr}(\mathrm{VI})$ and Congo red, respectively. This indicated the monolayer adsorption of $\mathrm{Cr}(\mathrm{VI})$ and Congo red on the energetically homogeneous active sites of the $\mathrm{PPy} / \mathrm{Fe}_{3} \mathrm{O}_{4} / \mathrm{SiO}_{2}$ nanocomposite. The regeneration study indicated the ability to reuse the nanocomposite several times for the removal of $\mathrm{Cr}(\mathrm{VI})$ and Congo red, which may reduce the overall cost of the treatment. Finally, we can conclude that the $\mathrm{PPy} / \mathrm{Fe}_{3} \mathrm{O}_{4} / \mathrm{SiO}_{2}$ nanocomposite is a promising material for water treatment and must be examined in the future for additional pollutant removal.

Author Contributions: Conceptualization, F.M.A., N.S.A., K.M.K., A.A., F.B.R., and M.A.T.; methodology, F.M.A., N.S.A., K.M.K., A.A., F.B.R., and M.A.T.; formal analysis, F.M.A., N.S.A., K.M.K., A.A., F.B.R., and M.A.T.; data curation, F.M.A., N.S.A., K.M.K., A.A., F.B.R., and M.A.T.; writing-original draft preparation, F.M.A., N.S.A., K.M.K., A.A., F.B.R., and M.A.T.; writing-review and editing, F.M.A., N.S.A., K.M.K., A.A., F.B.R., and M.A.T.; visualization, F.B.R. All authors have read and agreed to the published version of the manuscript.

Funding: This research was funded by Deanship of Scientific Research at King Khalid University.

Institutional Review Board Statement: Not applicable. 
Informed Consent Statement: Not applicable.

Data Availability Statement: Data sharing is not applicable.

Acknowledgments: The authors extend their appreciation to the Deanship of Scientific Research at King Khalid University, Abha-KSA, for funding this work through the General Research Project under grant number: GRP/144/42. Additionally, this research was funded by the Deanship of Scientific Research at Princess Nourah bint Abdulrahman University through the Fast-track Research Funding Program.

Conflicts of Interest: The authors declare no conflict of interest.

\section{References}

1. Siddeeg, S.M.; Tahoon, M.A.; Alsaiari, N.S.; Shabbir, M.; Ben Rebah, F. Application of Functionalized Nanomaterials as Effective Adsorbents for the Removal of Heavy Metals from Wastewater: A Review. Curr. Anal. Chem. 2021, 17, 4-22. [CrossRef]

2. Amari, A.; Elboughdiri, N.; Ghernaout, D.; Lajimi, R.H.; Alshahrani, A.M.; Tahoon, M.A.; Ben Rebah, F. Multifunctional crosslinked chitosan/nitrogen-doped graphene quantum dot for wastewater treatment. Ain Shams Eng. J. 2021. [CrossRef]

3. Amari, A.; Alzahrani, F.M.; Mohammedsaleh Katubi, K.; Alsaiari, N.S.; Tahoon, M.A.; Ben Rebah, F. Clay-Polymer Nanocomposites: Preparations and Utilization for Pollutants Removal. Materials 2021, 14, 1365. [CrossRef] [PubMed]

4. Shindhal, T.; Rakholiya, P.; Varjani, S.; Pandey, A.; Ngo, H.H.; Guo, W.; Ng, H.Y.; Taherzadeh, M.J. A critical review on advances in the practices and perspectives for the treatment of dye industry wastewater. Bioengineered 2021, 12, 70-87. [CrossRef] [PubMed]

5. Lin, J.; Zhang, X.; Li, Z.; Lei, L. Biodegradation of Reactive blue 13 in a two-stage anaerobic/aerobic fluidized beds system with a Pseudomonas sp. isolate. Bioresour. Technol. 2010, 101, 34-40. [CrossRef] [PubMed]

6. Yoo, J.-W.; Cho, H.; Lee, K.-W.; Won, E.-J.; Lee, Y.-M. Combined effects of heavy metals (Cd, As, and Pb): Comparative study using conceptual models and the antioxidant responses in the brackish water flea. Comp. Biochem. Physiol. Part C Toxicol. Pharmacol. 2021, 239, 108863. [CrossRef] [PubMed]

7. Suljević, D.; Sulejmanović, J.; Fočak, M.; Halilović, E.; Pupalović, D.; Hasić, A.; Alijagic, A. Assessing hexavalent chromium tissue-specific accumulation patterns and induced physiological responses to probe chromium toxicity in Coturnix japonica quail. Chemosphere 2021, 266, 129005. [CrossRef]

8. Shaban, M.; Abukhadra, M.R.; Khan, A.A.P.; Jibali, B.M. Removal of Congo red, methylene blue and Cr (VI) ions from water using natural serpentine. J. Taiwan Inst. Chem. Eng. 2018, 82, 102-116. [CrossRef]

9. Liu, J.; Xiong, J.; Tian, C.; Gao, B.; Wang, L.; Jia, X. The degradation of methyl orange and membrane fouling behavior in anaerobic baffled membrane bioreactor. Chem. Eng. J. 2018, 338, 719-725. [CrossRef]

10. Qiao, X.-Q.; Zhang, Z.-W.; Li, Q.-H.; Hou, D.; Zhang, Q.; Zhang, J.; Li, D.-S.; Feng, P.; Bu, X. In situ synthesis of n-n Bi 2 MoO 6 \& Bi 2 S 3 heterojunctions for highly efficient photocatalytic removal of Cr (VI). J. Mater. Chem. A 2018, 6, 22580-22589.

11. Feng, L.; Chen, W.-M.; Li, J.-L.; Day, G.; Drake, H.; Joseph, E.; Zhou, H.-C. Biological antagonism inspired detoxification: Removal of toxic elements by porous polymer networks. ACS Appl. Mater. Interfaces 2019, 11, 14383-14390. [CrossRef]

12. Wang, R.; Ng, D.H.; Liu, S. Recovery of nickel ions from wastewater by precipitation approach using silica xerogel. J. Hazard. Mater. 2019, 380, 120826. [CrossRef] [PubMed]

13. Pan, C.; Troyer, L.D.; Catalano, J.G.; Giammar, D.E. Dynamics of chromium (VI) removal from drinking water by iron electrocoagulation. Environ. Sci. Technol. 2016, 50, 13502-13510. [CrossRef]

14. Katubi, K.M.M.; Alsaiari, N.S.; Alzahrani, F.M.; M Siddeeg, S.; A Tahoon, M. Synthesis of Manganese Ferrite/Graphene Oxide Magnetic Nanocomposite for Pollutants Removal from Water. Processes 2021, 9, 589. [CrossRef]

15. Amari, A.; Katubi, K.M.; Alsaiari, N.S.; Alzahrani, F.M.; Ben Rebah, F.; Tahoon, M.A. Magnetic metal organic framework immobilized laccase for wastewater decolorization. Processes 2021, 9, 774. [CrossRef]

16. Delpiano, G.R.; Tocco, D.; Medda, L.; Magner, E.; Salis, A. Adsorption of Malachite Green and Alizarin Red S Dyes Using Fe-BTC Metal Organic Framework as Adsorbent. Int. J. Mol. Sci. 2021, 22, 788. [CrossRef]

17. Ihlenburg, R.B.; Lehnen, A.-C.; Koetz, J.; Taubert, A. Sulfobetaine Cryogels for Preferential Adsorption of Methyl Orange from Mixed Dye Solutions. Polymers 2021, 13, 208. [CrossRef] [PubMed]

18. Luca, P.D.; Chiodo, A.; Macario, A.; Siciliano, C.; B Nagy, J. Semi-Continuous Adsorption Processes with Multi-Walled Carbon Nanotubes for the Treatment of Water Contaminated by an Organic Textile Dye. Appl. Sci. 2021, 11, 1687. [CrossRef]

19. Alsaiari, N.S.; Katubi, K.M.M.; Alzahrani, F.M.; Siddeeg, S.M.; Tahoon, M.A. The Application of Nanomaterials for the Electrochemical Detection of Antibiotics: A Review. Micromachines 2021, 12, 308. [CrossRef] [PubMed]

20. Amari, A.; Al Mesfer, M.K.; Alsaiari, N.S.; Danish, M.; Alshahrani, A.M.; Tahoon, M.A.; Ben Rebah, F. Electrochemical and Optical Properties of Tellurium Dioxide (TeO2) Nanoparticles. Int. J. Electrochem. Sci. 2021, 16, 210235. [CrossRef]

21. Amari, A.; Alalwan, B.; Siddeeg, S.M.; Tahoon, M.A.; Alsaiari, N.S.; Ben Rebah, F. Biomolecules Behavior on a Surface of Boron Doped/un-doped Graphene Nanosheets. Int. J. Electrochem. Sci. 2020, 15, 11427-11436. [CrossRef]

22. Siddeeg, S.M.; Alsaiari, N.S.; Tahoon, M.A.; Ben Rebah, F. The application of nanomaterials as electrode modifiers for the electrochemical detection of ascorbic acid. Int. J. Electrochem. Sci. 2020, 15, 3327-3346. [CrossRef] 
23. Wang, X.-Y.; Jiang, X.-P.; Li, Y.; Zeng, S.; Zhang, Y.-W. Preparation Fe3O4 chitosan magnetic particles for covalent immobilization of lipase from Thermomyces lanuginosus. Int. J. Biol. Macromol. 2015, 75, 44-50. [CrossRef] [PubMed]

24. Jeelani, P.G.; Mulay, P.; Venkat, R.; Ramalingam, C. Multifaceted application of silica nanoparticles. A review. Silicon 2020, 12, 1337-1354. [CrossRef]

25. Cho, Y.; Shi, R.; Ivanisevic, A.; Borgens, R.B. A mesoporous silica nanosphere-based drug delivery system using an electrically conducting polymer. Nanotechnology 2009, 20, 275102. [CrossRef] [PubMed]

26. Dong, J.; Hu, Y.; Xu, J.; Qu, X.; Zhao, C. Nanocomposite with Polypyrrole Encapsulated within SBA-15 Mesoporous Silica: Preparation and Its Electrochemical Application. Electroanal. Int. J. Devoted Fundam. Pract. Asp. Electroanal. 2009, 21, 1792-1798. [CrossRef]

27. Ansari, R.; Fahim, N.K. Application of polypyrrole coated on wood sawdust for removal of Cr (VI) ion from aqueous solutions. React. Funct. Polym. 2007, 67, 367-374. [CrossRef]

28. Zhao, J.; Zhang, S.; Liu, W.; Du, Z.; Fang, H. Fe3O4/PPy composite nanospheres as anode for lithium-ion batteries with superior cycling performance. Electrochim. Acta 2014, 121, 428-433. [CrossRef]

29. Pirsa, S.; Aghbolagh Sharifi, K. A review of the applications of bioproteins in the preparation of biodegradable films and polymers. J. Chem. Lett. 2020, 1, 47-58.

30. Pirsa, S.; Asadzadeh, F.; Sani, I.K. Synthesis of Magnetic Gluten/Pectin/ $\mathrm{Fe}_{3} \mathrm{O}_{4}$ Nano-hydrogel and Its Use to Reduce Environmental Pollutants from Lake Urmia Sediments. J. Inorg. Organomet. Polym. Mater. 2020, 30, 3188-3198. [CrossRef]

31. Wang, Y.; Peng, X.; Shi, J.; Tang, X.; Jiang, J.; Liu, W. Highly selective fluorescent chemosensor for Zn 2+ derived from inorganicorganic hybrid magnetic core/shell Fe 3 O $4 @$ SiO 2 nanoparticles. Nanoscale Res. Lett. 2012, 7, 1-13.

32. Wang, J.-G.; Wei, B.; Kang, F. Facile synthesis of hierarchical conducting polypyrrole nanostructures via a reactive template of MnO 2 and their application in supercapacitors. Rsc Adv. 2014, 4, 199-202. [CrossRef]

33. Ayad, M.; Salahuddin, N.; Fayed, A.; Bastakoti, B.P.; Suzukic, N.; Yamauchi, Y. Chemical design of a smart chitosan-polypyrrolemagnetite nanocomposite toward efficient water treatment. Phys. Chem. Chem. Phys. 2014, 16, 21812. [CrossRef]

34. Cheng, Y.; Gao, F.; An, L.; Li, X.; Wang, G. Different combinations of Fe3O4 microsphere, Polypyrrole and silver as core-shell nanocomposites for adsorption and photocatalytic application. Adv. Powder Technol. 2014, 25, 1600-1607. [CrossRef]

35. Wang, G.; Chang, Y.; Wang, L.; Liu, C. Synthesis, characterization and microwave absorption properties of Fe3O4/Co core/shelltype nanoparticles. Adv. Powder Technol. 2012, 23, 861-865. [CrossRef]

36. Aigbe, U.; Ho, W.; Maity, A.; Khenfouch, M.; Srinivasu, V. Removal of hexavalent chromium from wastewater using $\mathrm{PPy} / \mathrm{Fe}_{3} \mathrm{O}_{4}$ magnetic nanocomposite influenced by rotating magnetic field from two pole three-phase induction motor. J. Phys. Conf. Ser. 2018, 948, 012008. [CrossRef]

37. Fu, Y.; Su, Y.-S.; Manthiram, A. Sulfur-polypyrrole composite cathodes for lithium-sulfur batteries. J. Electrochem. Soc. 2012, 159, A1420. [CrossRef]

38. Abbas, M.; Abdel-Hamed, M.; Chen, J. Efficient one-pot sonochemical synthesis of thickness-controlled silica-coated superparamagnetic iron oxide (Fe $3 \mathrm{O}$ 4/SiO 2) nanospheres. Appl. Phys. A 2017, 123, 775. [CrossRef]

39. Abbas, M.; Torati, S.R.; Kim, C. A novel approach for the synthesis of ultrathin silica-coated iron oxide nanocubes decorated with silver nanodots ( $\mathrm{Fe} 3 \mathrm{O}$ 4/SiO 2/Ag) and their superior catalytic reduction of 4-nitroaniline. Nanoscale 2015, 7, 12192-12204. [CrossRef] [PubMed]

40. Pirsa, S.; Alizadeh, N. Nanoporous conducting polypyrrole gas sensor coupled to a gas chromatograph for determination of aromatic hydrocarbons using dispersive liquid-liquid microextraction method. IEEE Sens. J. 2011, 11, 3400-3405. [CrossRef]

41. Bahador, F.; Foroutan, R.; Esmaeili, H.; Ramavandi, B. Enhancement of the chromium removal behavior of Moringa oleifera activated carbon by chitosan and iron oxide nanoparticles from water. Carbohydr. Polym. 2021, 251, 117085. [CrossRef] [PubMed]

42. Rambabu, K.; Bharath, G.; Banat, F.; Show, P.L. Biosorption performance of date palm empty fruit bunch wastes for toxic hexavalent chromium removal. Environ. Res. 2020, 187, 109694. [CrossRef] [PubMed]

43. Hsini, A.; Benafqir, M.; Naciri, Y.; Laabd, M.; Bouziani, A.; Ez-zahery, M.; Lakhmiri, R.; El Alem, N.; Albourine, A. Synthesis of an arginine-functionalized polyaniline@ FeOOH composite with high removal performance of hexavalent chromium ions from water: Adsorption behavior, regeneration and process capability studies. Colloids Surf. A Physicochem. Eng. Asp. 2021, 617, 126274. [CrossRef]

44. Hsini, A.; Naciri, Y.; Laabd, M.; El Ouardi, M.; Ajmal, Z.; Lakhmiri, R.; Boukherroub, R.; Albourine, A. Synthesis and characterization of arginine-doped polyaniline/walnut shell hybrid composite with superior clean-up ability for chromium (VI) from aqueous media: Equilibrium, reusability and process optimization. J. Mol. Liq. 2020, 316, 113832. [CrossRef]

45. Tahar, L.B.; Oueslati, M.H.; Abualreish, M.J.A. Synthesis of magnetite derivatives nanoparticles and their application for the removal of chromium (VI) from aqueous solutions. J. Colloid Interface Sci. 2018, 512, 115-126. [CrossRef]

46. Verma, A.; Chakraborty, S.; Basu, J.K. Adsorption study of hexavalent chromium using tamarind hull-based adsorbents. Sep. Purif. Technol. 2006, 50, 336-341. [CrossRef]

47. Hsini, A.; Naciri, Y.; Benafqir, M.; Ajmal, Z.; Aarab, N.; Laabd, M.; Navío, J.; Puga, F.; Boukherroub, R.; Bakiz, B. Facile synthesis and characterization of a novel 1, 2, 4, 5-benzene tetracarboxylic acid doped polyaniline@ zinc phosphate nanocomposite for highly efficient removal of hazardous hexavalent chromium ions from water. J. Colloid Interface Sci. 2021, 585, 560-573. [CrossRef]

48. Dognani, G.; Hadi, P.; Ma, H.; Cabrera, F.C.; Job, A.E.; Agostini, D.L.; Hsiao, B.S. Effective chromium removal from water by polyaniline-coated electrospun adsorbent membrane. Chem. Eng. J. 2019, 372, 341-351. [CrossRef] 
49. Siddeeg, S.M.; Amari, A.; Tahoon, M.A.; Alsaiari, N.S.; Ben Rebah, F. Removal of meloxicam, piroxicam and Cd+ 2 by $\mathrm{Fe} 3 \mathrm{O} 4 / \mathrm{SiO} 2 /$ glycidyl methacrylate-S-SH nanocomposite loaded with laccase. Alex. Eng. J. 2020, 59, 905-914. [CrossRef]

50. Chigondo, M.; Paumo, H.K.; Bhaumik, M.; Pillay, K.; Maity, A. Magnetic arginine-functionalized polypyrrole with improved and selective chromium (VI) ions removal from water. J. Mol. Liq. 2019, 275, 778-791. [CrossRef]

51. Alsaiari, N.S.; Amari, A.; Katubi, K.M.; Alzahrani, F.M.; Ben Rebah, F.; Tahoon, M.A. Innovative magnetite based polymeric nanocomposite for water treatment. Processes 2021, 9, 576. [CrossRef]

52. Karthikeyan, P.; Elanchezhiyan, S.S.; Preethi, J.; Meenakshi, S.; Park, C.M. Mechanistic performance of polyaniline-substituted hexagonal boron nitride composite as a highly efficient adsorbent for the removal of phosphate, nitrate, and hexavalent chromium ions from an aqueous environment. Appl. Surf. Sci. 2020, 511, 145543. [CrossRef]

53. Sun, W.; Zhou, Y.; Su, Q.; Chen, L.; Wang, Y.; Liu, J.; Sun, Y.; Ma, H. Removal of chromium (VI) from aqueous solutions using polypyrrole-based magnetic composites. Polym. Bull. 2017, 74, 1157-1174. [CrossRef]

54. Wang, H.; Yuan, X.; Wu, Y.; Chen, X.; Leng, L.; Wang, H.; Li, H.; Zeng, G. Facile synthesis of polypyrrole decorated reduced graphene oxide-Fe3O4 magnetic composites and its application for the Cr (VI) removal. Chem. Eng. J. 2015, 262, 597-606. [CrossRef]

55. Ballav, N.; Choi, H.J.; Mishra, S.B.; Maity, A. Polypyrrole-coated halloysite nanotube clay nanocomposite: Synthesis, characterization and Cr (VI) adsorption behaviour. Appl. Clay Sci. 2014, 102, 60-70. [CrossRef]

56. Bhaumik, M.; Maity, A.; Srinivasu, V.; Onyango, M.S. Removal of hexavalent chromium from aqueous solution using polypyrrolepolyaniline nanofibers. Chem. Eng. J. 2012, 181, 323-333. [CrossRef]

57. Ballav, N.; Maity, A.; Mishra, S.B. High efficient removal of chromium (VI) using glycine doped polypyrrole adsorbent from aqueous solution. Chem. Eng. J. 2012, 198, 536-546. [CrossRef]

58. Bhaumik, M.; Maity, A.; Srinivasu, V.; Onyango, M.S. Enhanced removal of Cr (VI) from aqueous solution using polypyrrole/Fe3O4 magnetic nanocomposite. J. Hazard. Mater. 2011, 190, 381-390. [CrossRef]

59. Ballav, N.; Choi, H.; Mishra, S.; Maity, A. Synthesis, characterization of Fe3O4@ glycine doped polypyrrole magnetic nanocomposites and their potential performance to remove toxic Cr (VI). J. Ind. Eng. Chem. 2014, 20, 4085-4093. [CrossRef]

60. Amalraj, A.; Selvi, M.K.; Rajeswari, A.; Pius, A. Preparation and characterization of aspartic acid doped polypyrrole for the efficient removal of Cr (VI) from aqueous solution. J. Water Process Eng. 2016, 11, 162-173. [CrossRef]

61. Zhang, Z.; Zhu, W.; Wang, R.; Zhang, L.; Zhu, L.; Zhang, Q. Ionothermal confined self-organization for hierarchical porous magnesium borate superstructures as highly efficient adsorbents for dye removal. J. Mater. Chem. A 2014, 2, 19167-19179. [CrossRef]

62. Lorenc-Grabowska, E.; Gryglewicz, G. Adsorption characteristics of Congo Red on coal-based mesoporous activated carbon. Dye. Pigment. 2007, 74, 34-40. [CrossRef]

63. Zhao, J.; Tan, Y.; Su, K.; Zhao, J.; Yang, C.; Sang, L.; Lu, H.; Chen, J. A facile homogeneous precipitation synthesis of NiO nanosheets and their applications in water treatment. Appl. Surf. Sci. 2015, 337, 111-117. [CrossRef]

64. Li, X.; Xiao, W.; He, G.; Zheng, W.; Yu, N.; Tan, M. Pore size and surface area control of MgO nanostructures using a surfactanttemplated hydrothermal process: High adsorption capability to azo dyes. Colloids Surf. A Physicochem. Eng. Asp. 2012, 408, 79-86. [CrossRef]

65. Bhattacharyya, K.G.; Sharma, A. Azadirachta indica leaf powder as an effective biosorbent for dyes: A case study with aqueous Congo Red solutions. J. Environ. Manag. 2004, 71, 217-229. [CrossRef]

66. Zhai, Y.; Zhai, J.; Zhou, M.; Dong, S. Ordered magnetic core-manganese oxide shell nanostructures and their application in water treatment. J. Mater. Chem. 2009, 19, 7030-7035. [CrossRef]

67. Wang, L.; Wang, A. Adsorption characteristics of Congo Red onto the chitosan/montmorillonite nanocomposite. J. Hazard. Mater. 2007, 147, 979-985. [CrossRef] [PubMed]

68. Li, Z.; Hanafy, H.; Zhang, L.; Sellaoui, L.; Netto, M.S.; Oliveira, M.L.S.; Seliem, M.K.; Dotto, G.L.; Bonilla-Petriciolet, A.; Li, Q. Adsorption of congo red and methylene blue dyes on an ashitaba waste and a walnut shell-based activated carbon from aqueous solutions: Experiments, characterization and physical interpretations. Chem. Eng. J. 2020, 388, 124263. [CrossRef]

69. Cseri, L.; Topuz, F.; Abdulhamid, M.A.; Alammar, A.; Budd, P.M.; Szekely, G. Electrospun Adsorptive Nanofibrous Membranes from Ion Exchange Polymers to Snare Textile Dyes from Wastewater. Adv. Mater. Technol. 2021, 2000955. [CrossRef] 